\title{
APORIE HLEDÁNÍ BOHA V PAMĚTI \\ Význam analýzy paměti \\ v X. knize Augustinových Vyznání
}

\section{Alena Roreitnerová}

Současné filosofické interpretace Vyznání (Confessiones), zejména I. a X. knihy, v nejednom př́padě chápou otázku, kterou si tu Augustin klade - totiž otázku hledání Boha -, jako určitou variantu Menónova paradoxu: jak Boha hledat, když jsme jej dosud nepoznali? Je vůbec možné mít $\mathrm{k}$ němu intencionální vztah, např. toužit po jeho poznání, jestliže jej neznáme? A jak poznáme, že jsme našli, co jsme hledali? Pomyslným orientačním bodem takového pátrání má být podle X. knihy Vyznání implicitní poznání blaženého života, které všichni lidé mají ve své paměti. Augustin svou reflexi tohoto poznání postupně rozvine do formulace, podle níž je beata vita radostí z pravdy (gaudium de veritate). Interpretace, které sledují motiv Menónovy aporie, se proto obvykle zaměřují na obě tyto komponenty blaženosti, případně zkoumají, v jakém smyslu je pravda předmětem radosti. Následující text nejprve ve zkratce ukazuje, jaké místo má aporie hledání ve Vyznáních jako celku. V druhé části se soustředí na povahu samotného spojení gaudium de veritate, jehož vysvětlení předpokládá detailnější četbu analýzy paměti z X. knihy. V jakémsi drobnohledu si přitom všímá zvláštního významu, který tu Augustin přikládá vzpomínce na minulou radost.

\section{Hledání a rozpoznání}

Třebaže mají být Vyznání podle slov samotného autora vlastní biografií spojenou s výkladem začátku knihy Genesis, ${ }^{1}$ zůstávají především spisem, v němž Augustin vypráví o svém hledání Boha. Toto hledání je v prvních devíti knihách vylíčeno jako singulární příběh, v desáté knize str. 94.

1 Srv. Augustin, Retract. II,6,1 /CCL 57, vyd. A. Mutzenbecher, Turnhout 1984, 
se ale mění v introspektivní zkoumání, které si činí nárok na universalitu. ${ }^{2}$ Reflexe povahy paměti se už nezaměřuje jen na její jednotlivé obsahy, jako tomu bylo při vyprávění, ale spíše na různé kategorie těchto obsahů, které jsou ve své obecnosti rozlišitelné pro každého. Právě universální povaha této typologie pamět'ových obsahů bude mít pro otázku hledání Boha zvláštní význam, a to zejména v případě všeobecně sdílené obeznámenosti (notitia) s blaženým životem, která se - jak ještě uvidíme - stane jakýmsi prvním krokem Augustinova řešení aporie hledání.

Je však třeba předeslat, že otázka hledání Boha se filosofickému (a vlastně ani náboženskému) myšlení nenabízí sama od sebe a pro mnohé myslitele se jednoduše neklade jako problém. Intencionální postoj hledání, sám o sobě dosti nesamozřejmý, je nicméně příznačný právě pro Augustina, a to už od jeho raných cassiciackých dialogů (sepsaných $\mathrm{v}$ roce $386, \mathrm{v}$ době jeho filosofických prázdnin předcházejících křtu v Miláně). Už tady je motiv hledání Boha zřetelně spojen s tématem blaženosti, přesněji řečeno otázka možného poznání Boha je často jen naznačena nebo zmíněna, zatímco se výslovně a setrvaleji rozvíjí Ciceronem inspirované tázání, zda a jak můžeme dosáhnout blaženého života (beata vita). ${ }^{3}$ Beata vita je v těchto úvahách, namířených zčásti proti

2 Jestliže Augustin v X. knize píše sám o sobě, je tomu tak - jak alespoň tvrdí proto, že si jeho pomyslní čtenáři přejí vědět, kým nyní je a jaký je. Srv. týž, Confess. X,3,4 / CCL 27, vyd. L. Verheijen, Turnhout 1970, str. 156 (quis sim), tamt., X,4,6 / CCL 27,157 (qualis sim), resp. tamt., X,4,6 / CCL 27,158 (quis iam sim et quis adhunc sim). Srv. dále tamt., X,5,7; 6,9 / CCL 27,158; 159 n. A třebaže se této otázce nijak nevyhýbá, zároveň své adresáty explicitně nabádá, aby se nezajímali ani tak o něj, jako spíše sami o sebe. Tím dostává celá X. kniha výrazně protreptické vyznění. Pokud jde o překlady Vyznání, lze jedině doporučit jak překlad Ondřeje Koupila, Marie Kyralové a Pavla Mareše vydaný v Karmelitánském nakladatelství - Kostelní Vydří 2015 a 2019 -, tak zatím nejnovější překlad knih I-IX z pera Jiř́ího Šubrta vydaný v Oikúmené - Praha 2019. V tomto textu - především z důvodu sledování terminologické stránky originálu - pracuji s překlady vlastními, není-li uvedeno jinak.

3 K otázce vzájemného vztahu blaženého života a poznání Boha srv. (1) Augustin, Contra Acad. I,1,3, vyd. W. M. Green, CCL 29, Turnhout 1970, str. 5: Ipsa [philosophia] verissimum et secretissimum Deum perspicue se demonstraturam promittit, et iam iamque quasi per lucidas nubes ostentare dignatur. Pokud jde o Augustinův zpětný pohled na tento spis ve věci vztahu blaženého života a Boha, srv. týž, Retract., zejm. I,1,3 / CCL 57,9: Sine controversia ergo quaedam originalis regio beatitudinis animi Deus ipse est..., (2) týž, De beata vita, 2,11 / CCL 29,72: Deum igitur, inquam, qui habet, beatus est. K deklarovanému obsahu De beata vita srv. ohlédnutí v týž, Retract. I,2 / CCL 57,11: In quo libro constitit inter nos, qui simul quaerebamus, non esse beatam vitam nisi perfectam cognitionem Dei. (3) Týž, De ord. II,18,47 / CCL 29,133: duplex quaestio est: una de anima, altera de Deo. Prima efficit, ut nosmet ipsos noverimus, altera, ut originem nostram. Illa 
skeptikům, spjata nejen s hledáním, nýbrž s nalezením pravdy, které zároveň přináší moudrost ve smyslu cíle filosofického usilování. ${ }^{4} \mathrm{Sa}$ motné hledání pravdy, moudrosti či blaženého života (a vposled Boha) je tedy $\mathrm{v}$ těchto raných rozhovorech zčásti problematizováno, nakolik nemá zůstat samo o sobě cílem (blažený totiž není ten, kdo nemá, co hledá). ${ }^{5}$ Současně je ale výslovně vyžadováno, aby člověk po Bohu pátral $\mathrm{a}-\mathrm{s}$ oporou v biblických textech - věril, že to, co hledá, také nalezne. ${ }^{6}$ Nápadné je to např. v rozhovoru $O$ blaženém životě (De beata vita), kde Monika v odpověd’ na otázku, zda Bůh chce, aby jej člověk hledal, dokonce kategoricky praví, že Boha nenajdou ti, kdo jej napřed nehledali. ${ }^{7} \mathrm{~V}$ tomto raném dialogu přitom ještě není vyloučeno, že by ten, kdo Boha již nalezl a vede dobrý život, mohl být blažený, ${ }^{8}$ jakkoli je tato

nobis dulcior, ista carior, illa nos dignos beata vita, beatos haec facit; prima est illa discentibus, ista iam doctis. (4) Srv. též k hledání Boha: týž, Solil. I,1,6 / CSEL 89, vyd. W. Hörmann, Wien 1986, str. 10: Fac et me, Pater, vindica me ab errore; quaerenti te mihi nihil aliud pro te occurrat; dále tamt., I,2,7 / CSEL 89,11: Deum et animam scire cupio. Pokud jde o vztah blaženého života a poznání Boha, srv. tamt., I,7,14 / CSEL 89,22-23: Item quia in ista vita, quamquam Deo intellecto anima iam beata sit... K tomu srv. týž, Retract. I,4,3 / CCL 57,14: Nec illud mihi placet, quod in ista vita Deo intellecto iam beatam esse animam dixi, nisi forte spe. (Srv. týž, Solil. II,20,36 / CSEL 89,98: Bono animo esto. Deus aderit, ut iam sentimus, quaerentibus nobis, qui beatissimum quiddam post hoc corpus, et veritatis plenissimum sine ullo mendacio pollicetur.)

4 Explicitní ztotožnění Boží moudrosti s Kristem je tu zatím zmiňováno spíšs okrajově. Srv. týž, De beata vita, 4,34 / CCL 29,84: Dei Filium nihil esse aliud quam Dei sapientiam (1K 1,24). (Srv. týž, Contra Acad. II,1,1 / CCL 29,18.) Srv. k tomu L. Karfíková, Sapientiae amor, in: táž, Filosofie Augustinova mládí, Praha 2016, zejm. str. 10-11.

5 Srv. Augustin, Contra Acad. I,5,14 / CCL 29,12: beatum igitur faciet non tantum inventio, sed ipsa per se investigatio veritatis. Jde o výslovně odmítnuté stanovisko.

6 Augustin cituje Mt 7,7 již v Contra Acad. II,3,9 / CCL 29,23. V Písmu bychom ovšem našli i tvrzení opačná, např. $J 7,34$.

7 Týž, De beata vita, 3,19 / CCL 29,76: Sed nemo, inquit, potest pervenire ad Deum, nisi Deum quaesierit. Takto silné tvrzení by patrně oporu v biblických textech nenašlo (srv. Iz 65,1). Sama pobídka k hledání samozřejmě oporu má (např. Dt 4,29; Jr 29,13; Mt 7,8; L 11,10); srv. týž, Confess. IX,11,28 / CCL 27,149, kde Monika parafrázuje $S k$ 17,27.

8 Augustin (De beata vita, 3,21 / CCL 29,77) v pomyslné množině těch, kdo Boha hledají, rozlišuje mezi tím, kdo Boha našel, vede dobrý život, je blažený a „má“ Boha „příznivě nakloněného“ (propitium), a tím, kdo Boha teprve hledá - nemá jej nijak (ani příznivě, ani „nepříznivě“) nakloněného -, a přece není zcela bez něj (sine Deo). 
možnost v samotném závěru rozmluvy zpochybněna. ${ }^{9} \mathrm{~V}$ každém př́padě přesvědčení o tom, že blaženosti lze dosáhnout až v eschatologicky budoucím životě (futura vita), postupem času ve spisech hipponského biskupa spíše vzrůstá. ${ }^{10}$ Augustinovo hledání v sobě tedy spojuje - nejen v raných dialozích - téměř neslučitelné momenty: jelikož nesmí zůstat samoúčelné, musí být, nakolik to jde, otevřené možnosti skutečného nalezení hledaného, ačkoli je zřejmé, že v tomto životě nemůže být nikdy zcela završeno.

\subsection{Menónova aporie}

Pokud jde o samotná Vyznání, existuje interpretační linie, která si všímá, že zejména I. a X. kniha tohoto spisu formuluje otázku hledání Boha jako aporii nikoli nepodobnou té, kterou známe z Platónova dialogu Menón. ${ }^{11}$ Dříve než se pokusíme k tomuto výkladovému směru připojit několik poznámek, připomeňme si ve zkratce Menónovy otázky: ${ }^{12}$ (1) Jak máme hledat něco, o čem nevíme, co to je? (2) A pokud bychom to našli, jak poznáme, že jde o to, co jsme hledali? První otázka se týká východiska a zacílení hledání, druhá pak rozpoznání hledaného. ${ }^{13}$ Jinými slovy, v prvním případě se jedná o počátek hledání a o samu možnost

9 Srv. týž, De beata vita, 4,35 / CCL 29,84: Sed tamen quamdiu quaerimus, nondum ipso fonte atque, ut illo verbo utar, plenitudine saturati nondum ad nostrum modum nos pervenisse fateamur et ideo quamvis iam Deo adiuvante nondum tamen sapientes ac beati sumus. K Augustinovu pojetí blaženosti srv. W. Beierwaltes, Regio beatitudinis, Villanova 1981.

10 Srv. Augustin, Retract. I,2 / CCL 57,11. Augustin bude později argumentovat, že blažený život není možný bez toho, aby byl člověk nesmrtelný, resp. spasený. Srv. mj. týž, De Trin. XIII,7,10 / CCL 50, vyd. W. J. Mountain, Turnhout 1968, str. 396; De civ. Dei, XIX,4 / CCL 48, vyd. B. Dombart - A. Kalb, Turnhout 1955, str. 668-669 ad.

$11 \mathrm{O}$,theologické verzi paradoxu hledání“ ve Vyznáních se zmiňuje G. B. Matthews ve svém článku věnovaném spisu O Trojici (Augustine on the Mind's Search for Itself, in: Faith and Philosophy. Journal of the Society of Christian Philosophers, 20, 2003, str. 415). S tímto textem pracuje ve svém článku zaměřeném přímo na menónovskou aporii ve Vyznáních Scott Macdonald, The Paradox of Inquiry in Augustine's Confessions, in: Metaphilosophy, 39, 2008, str. 20-38. Na něj pak zčásti kriticky reaguje S. Menn, The Desire for God and the Aporetic Method in Augustine's Confessions, in: W. E. Mann (vyd.), Augustine's Confessions. Philosophy in Autobiography, Oxford 2014, str. 71-107.

12 Srv. tři Menónovy otázky (Meno, 80d5-8) a Sókratovu reformulaci v podobě dilematu (80e1-6).

13 Srv. G. B. Matthews, Augustine on the Mind's Search for Itself, str. 420, který rozlišuje tzv. „targeting objection“ a „recognition objection“. Toto rozlišení přejímá S. Macdonald, The Paradox of Inquiry, str. 22. 
intencionálního vztahu k čemusi, co neznáme, ${ }^{14}$ zatímco v druhém jde o to, jak charakterizovat poznání, resp. vědění (coby odlišné od víry nebo správného mínění).

Jde-li o první otázku: jestliže Menón formuluje svou „eristickou námitku“, podle níž je veškeré hledání vposledku nesmyslné, pro Sókratovu pozici je naopak příznačné neodbytné přesvědčení, že je třeba vytrvale hledat i to, o čem nemáme žádné vědění ${ }^{15} \mathrm{Jak}$ je ale něco takového možné? Nejprve je třeba vyvrátit domnělé vědění ( $\mathrm{tj}$. vést do aporie), pak teprve lze hledat - alespoň ve věci správného jednání - jakési předběžné odpovědi založené na důvěře ve správné mínění: do Larisy nás může dovést nejen někdo, kdo tam již jednou šel, ale také někdo, kdo má o cestě pravdivé mínění. ${ }^{16}$ Potíž mínění coby vodítka však tkví jednak v tom, že nás zhusta vede cestou pokusu a omylu, ${ }^{17}$ jednak v jeho nestálosti. Proto je třeba svázat je posléze ,rozumovým výkladem příčiny“ ${ }^{18}$ Především tato poslední možnost, jak dospět od správného mínění ke skutečnému vědění, je vysvětlena poukazem k platónské anamnésis (ačkoli je třeba hned dodat, že Sókratés popisuje jako vzpomínání už první krok hledání, stejně jako druhý krok, jímž je nacházení správných mínění). ${ }^{19}$ Jakousi předběžnou sókratovskou odpovědí na první Menónovu otázku po možnosti hledání něčeho, co dosud neznáme, je tedy důvěra ve směrodatnost správného mínění. Odpověd’ na druhou otázku, tedy jak vůbec rozpoznáme, že jsme našli, co jsme hledali, má přinést teorie rozpomínky. Tento zatím velmi schematický popis Menónovy aporie hledání ctnosti či zdatnosti se snad stane plastičtějším, až si více přiblížíme Augustinovy vlastní peripetie hledání.

\subsection{Předznamenání paradoxu hledání v I. knize Vyznání}

Na samém začátku své autobiografie vyjadřuje Augustin touhu chválit (laudare) Boha; už zde se přitom objevuje první náznak aporie hledání, a sice ve vstupní otázce, která je volně inspirována Pavlovým Listem

14 Takto formuluje jádro aporie S. Menn, The Desire for God, str. 84. Otázce intencionality se budeme věnovat níže v podkapitole Problém intencionality.

15 Platón, Meno, 81e2-5; 86b-c.

16 Tamt., 97a10-c3.

17 Srv. např. pasáž s řešením geometrické úlohy (Platón, Meno, 82b-85b). K tomu srv. G. Fine, Inquiry in the Meno, in: R. Kraut (vyd.), The Cambridge Companion to Plato, Illinois 1992, str. 200-226, k metodě pokusu a omylu zejm. str. 211.

18 Platón, Meno, 98a2.

19 Srv. tamt., 81c5-d5; 85c6-d8; 97e6-98a8. 
Římanům: ${ }^{20}$ Jak někdo může Boha chválit a vzývat, jestliže jej nezná, táže se mluvčí Vyznání. Obává se totiž, aby neznaje, koho hledá, nevzýval namísto něj kohosi jiného. Podobná možnost záměny není pro někdejšího vyznavače manichejství jen pouhou hypotézou. ${ }^{21} \mathrm{O}$ to důležitějš́ je v celkovém záměru Vyznání snaha Boha nejen chválit (laudare) a vzývat (invocare), ale také poznat (scire).

Zdá se přitom, že Augustin zakládá optimistický předpoklad možného nalezení hledaného na autoritě biblických textů. ${ }^{22} \mathrm{Z}$ nich je vyvozena souslednost aktivit, které mají vposledku vést k zamýšlené chvále Boha: jestliže byl Bůh hlásán (praedicare), pak je možné v něj uvěřit (credere) a následně jej také vzývat (invocare); otázka nejistého předmětu tohoto vzývání ale vyžaduje jeho skutečné poznání (scire), které zas předpokládá hledání (requirere, resp. quaerere). Ti, kdo hledají, však podle evangelí́ také nalézají (invenire), a proto, jak dovozuje Augustin, nakonec také Boha chválí (laudare). ${ }^{23}$ Při bližším pohledu se však ukazuje, že důraz na motiv poznání (scire) vnáší do této vstupní úvahy Augustin sám, ${ }^{24}$ aniž by jej výslovně odvozoval z Písma (ačkoli by mohl a jinde tak činî) ${ }^{25}$ Některé jeho formulace evokují spíše sókratovské zkoumání, které má vést $\mathrm{k}$ vědění coby schopnosti podat výměr, jak lze přinejmenším soudit z explicitní otázky vyjádřené o několik odstavců níže: „Co tedy jsi, můj Bože?“" (Quid es ergo Deus meus?) ${ }^{26}$ Skutečnost, že Augustinovi nejde o nic menšího než o poznání Boha, se ukáže jasněji, pokud vedle sebe položíme I. knihu a knihu X, která začíná slovy: „At' poznávám tebe, který mne znáš, at’ tě poznávám tak, jako jsem sám [tebou] poznán.“"27 Záhy se také opakovaně vrací otázka „A co to je?“ (Et quid

20 Srv. Augustin, Confess. I,1,1 / CCL 27,1: Sed quis te invocat nesciens te? ... Quomodo autem invocabunt, in quem non crediderunt? Aut quomodo credunt sine praedicante? Srv. $\check{R} 10,13-14$.

21 Viz např. týž, Solil. I,1,6 / CSEL 89,10. Srv. k tomu J. J. O’Donnell, Augustine. Confessions, I, Oxford 1992, str. 15; G. B. Matthews, Augustine on the Mind's Search for Itself, str. 415.

22 Kromě již uvedené pasáže jde také o Ž 21,27 a Augustinem často citované místo z $M t 7,7-8$, resp. $L 11,10$.

23 K této pasáži srv. J. J. O’Donnell, Augustine. Confessions, I, str. 15. Srv. též S. Macdonald, The Paradox of Inquiry, str. 23-27.

24 Srv. Augustin, Solil. I,2,7 (citováno výše, pozn. 3).

25 Srv. např. týž, De lib. arb. II,2,6 / CCL 29,239.

26 Týž, Confess. I,4,4 / CCL 27,2.

27 Tamt., X,1,1 / CCL 27,155: Cognoscam te, cognitor meus, cognoscam, sicut et cognitus sum. Srv. $1 K 13,12$. 
est hoc? $)^{28} \mathrm{O}$ něco dále se Augustin podobně jako v úvodních odstavcích Vyznání ptá, kde má Boha najít a jak jej má vůbec hledat. ${ }^{29}$ Celá X. kniha pak končí slovy: „A chválí Pána, kdo jej hledaji““ (et laudant Dominum qui requirunt eum), která jsou zřetelným ozvukem úplného začátku spisu (v X. knize je však už sloveso laudare - na rozdíl od úvodní věty díla v přítomném, a nikoli budoucím čase). ${ }^{30}$ Skutečnost, že Augustin sleduje motiv hledání a nalézání ve své duchovní autobiografii jako celku, lze snad doložit také poslední větou celých Vyznání, jež opět parafrázuje Mt 7,7-8, resp. $L$ 11,10: ,at' v tobě hledáme..., a tak nalezneme“ (in te quaeratur ... sic invenietur...). ${ }^{31}$

Problém hledání tedy rámuje spis jako celek a hojnost biblických citací či parafrází má být dokladem toho, že úsilí poznat Boha podle Augustina čerpá svou naději z Písma. Pokusíme se však ukázat, že v X. knize Vyznání je rozvinuta ještě jiná hypotéza o počátku hledání dosud nepoznaného: Augustin zde uvažuje o tom, jakou podobu může mít hledání ještě předtím, než se pro někoho Písmo stane závaznou autoritou a prvotním zdrojem poznání, a proč něco takového člověk vůbec podniká. ${ }^{32}$

1.3 Jak je možné hledat něco, o čem nevíme, co to je?

Pokud bychom měli výše načrtnuté schéma Menónovy aporie převést na Augustinův případ, na první pohled by se zdálo, že pro Augustina je průvodcem hledání - analogicky k sókratovské doxa - víra (fides) opírající se o autoritu Písma, jak jsme to viděli v I. knize. Ve Vyznáních jako celku je přitom řeč také, a snad především, o skrytém vedení vnitřním světlem, ${ }^{33}$ této metafoře je ale zapotřebí teprve správně porozumět. Zůstaneme-li prozatím u toho, že hledání vychází z fides - odlišné od domněnky (opinio), která má často negativní zabarvení -, lze Vyznáním

28 Tamt., X,6,9 / CCL 27,159.

29 Tamt., X,17,26; 20,29 / CCL 27,169; 170. Srv. J. J. O’Donnell, Augustine. Confessions, III, Oxford 1992, str. 190.

30 Augustin, Confess. X,43,70 / CCL 27,193.

31 Tamt., XIII,38,53 / CCL 27,273.

32 Přesněji řečeno, Augustin nikde ve Vyznáních neř́íká, že by Písmo nechápal jako autoritu, spíše líčí, jak pro něj bylo zprvu překážkou. K tomuto motivu se vrátíme níže v podkapitole Problém orientace.

33 Srv. např. týž, Confess. II,8,16 / CCL 27,25 atd. K myšlence skrytého Božího průvodcovství srv. tamt., VI,5,8; X,4,6 / CCL 27,79; 158 ad. 
rozumět v duchu myšlenky fides quaerens intellectum. ${ }^{34}$ Toto uvažování Augustinovi bezpochyby není cizí, jeho exemplární vyjádření najdeme mj. ve spise $O$ svobodném rozhodování (De libero arbitrio), kde stručně řečeno praví, že nalézt (invenire) Boha neznamená věřit v něj, aniž bychom jej poznali, zároveň ale ona inventio není možná, jestliže jsme $\mathrm{v}$ to, co má být teprve poznáno, napřed neuvěrili. ${ }^{35} \mathrm{Zde}$ je víra nutnou podmínkou poznání, třebaže není podmínkou dostačující.

\subsubsection{Problém orientace}

V Augustinově duchovní biografii je však celá věc o něco složitější, nebot' trajektorie hledání zobrazená v její narativní části načrtává linii, která je přinejmenším velmi nepřímá. Na jednu stranu o sobě Augustin referuje jako o člověku, jenž věří navzdory pochybnostem: např. v VI. knize tvrdí, že ačkoli byl v době, kdy navštěvoval Ambrožova kázání, stále přesvědčeným akademikem, přesto jej žádné rozepře mezi filosofy nemohly uvést v takovou pochybnost, aby nevěril, že Bůh je a že se stará o lidské věci. V této době ale ještě nezná podstatu (substantia) Boha ani nezná cestu, která $\mathrm{k}$ němu vede či znovu přivádí. ${ }^{36}$ (Co jiného je ostatně stav aporie?) V tomto smyslu pro Augustina i ve Vyznáních platí, že víra je nutnou podmínkou poznání, sama o sobě však není tímtéž, co „nalezení“.

Přesto však ze III. knihy víme, že tím, co ve skutečnosti uvedlo Augustinovo obrácení do pohybu, nebylo Písmo, nýbrž Ciceronův dialog Hortensius: „Ta kniha nasměrovala má vnitřní hnutí (affectum) jinam, mé modlitby obrátila $\mathrm{k}$ Tobě samému, Pane, a proměnila má přání a touhy..., takže jsem začal povstávat, abych se k tobě vrátil.“37 Citovaný popis zřejmě retrospektivně promítá výsledek hledání do samotného

$34 \mathrm{~K}$ rozdílu intellegere, credere a opinari srv. týž, De util. cred. 11,25, vyd. J. Zycha, CSEL 25, Wien 1891, str. 32.

35 Týž, De lib. arb. II,2,6 / CCL 29,239: Deinde [Dominus] iam credentibus dicit: Quaerite et invenientis [Mt 7,7]; nam neque inventum dici potest quod incognitum creditur neque quisquam inveniendo Deo fit idoneus, nisi ante crediderit quod est postea cogniturus. Podobně je tomu i v pozdějších spisech. Srv. týž, De Trin. XIII,20,25 / CCL 50,417-418, kde je řeč o víře jako předpokladu zdařilého usilování o blažený život.

36 Týž, Confess. VI,5,7-8 / CCL 27,78: quae via duceret aut reduceret ad te.

37 Srv. tamt., III,4,7 / CCL 27,30: Ille vero liber mutavit affectum meum et ad te ipsum, Domine, mutavit preces meas et vota ac desideria mea fecit alia. Viluit mihi repente omnis vana spes et immortalitatem sapientiae concupiscebam aestu cordis incredibili et surgere coeperam, ut ad te redirem. 
počátku tohoto procesu; pro danou situaci je proto přiléhavější Augustinovo tvrzení, že jej tento text přiměl hledat „nesmrtelnost moudrosti“ (immortalitas sapientiae). ${ }^{38}$ Už výše jsme přitom naznačili, že Augustin spolu úzce spojuje moudrost a blaženost $;^{39}$ podle svědectví jeho spisu O Trojici zahrnoval Ciceronův Hortensius tvrzení, že „,v̌̌ichni chtějí být blažení“ (omnes beati esse volunt)..$^{40}$ Jak ještě uvidíme, právě tato teze, která zaznívá např́č Augustinovými ranými i pozdějšími díly jako jakýsi axióm, jenž není nikdy uveden v pochybnost ${ }^{41}$ je i pro otázku hledání Boha ve Vyznáních rozhodující.

Na druhou stranu je pozoruhodné, že první spis, který Augustin podle svého svědectví bere po této „filosofické konverzi“ do rukou, je Písmo. V té době se mu však jeví v porovnání s Ciceronem přinejmenším co do formy nedůstojné, a proto je opět odkládá ${ }^{42}$ Tím se mu, jak známo, otevírá př́ístup $\mathrm{k}$ manichejství a jeho pátrání tak sice nekončí, ale dostává se na „scestí“", které se zpětně jeví jako téměř dvanáctiletá digrese. ${ }^{43}$ Role Písma je tedy zpočátku ambivalentní. (A není dokonce vyloučeno, že - z hlediska autobiografie jako celku - může tato jeho dvojznačná pozice vysvětlit, proč autor v závěrečných knihách Vyznání věnuje tolik pozornosti biblické knize Genesis: rozvíjení Ambrožovy exegetické metody snad mělo především ukázat, jak hledat moudrost a blaženost tam, kde Augustin zprvu sám narazil na překážku. $)^{44}$ Jestliže je tedy pro první Menónovu otázku určující, čím se nechává hledání vést, aby mohlo dojít ke kýženému cíli, Augustinova odpověd’ zůstává, jak se zdá, dvojí:

38 Srv. Augustinovo vyjádření ve spise De beata vita, 1,4 / CCL 29,66, kde svůj vnitřní stav vyvolaný četbou Hortensia popisuje spíše jako lásku k filosofii.

39 Srv. např. tamt., 4,27-4,34 / CCL 29,80-84; týž, De lib. arb. II,9,26 / CCL 29,254 .

40 Srv. Cicero, Hortensius, zl. 58, vyd. A. Grilli, Milano 1962. Srv. Augustin, De Trin. XIII,4,7 / CCL 50,390 n.

41 Výslovnou referenci najdeme kromě Augustinova dialogu De beata vita, 2,10 / CCL 29,70 nebo Contra Acad. I,2,5 / CCL 29,6 např. i v jeho De civ. Dei, X,1 / CCL 47,271, vyd. B. Dombar - A. Kalb, Turnhout 1955. V De Trin. XIII,4,7 / CCL 50,390-391 Augustin o tomto tvrzení ř́́ká, že jej dokonce ani skeptikové nezpochybňují, a podobně se vyjadřuje i v Contra Jul. VI,26,12, vyd. M. Zelzer (post E. Kalinka), CSEL 85/2, Wien 1974, str. 392, i v dalších spisech.

42 Srv. týž, Confess. III,5,9 / CCL 27,31. Není nikde řečeno, co z Písma Augustin četl (jde nicméně zřejmě o první setkání s Biblí vůbec, alespoň nakolik o nich Augustin referuje). Srv. J. J. O’Donnell, Augustine: Confessions, II, str. 170.

43 Srv. Augustin, Confess. VIII,7,17 / CCL 27,124. (Srv. též VI,11,18 / CCL 27,85 n.)

44 Srv. k tomu S. Menn, The Desire for God, str. 76-78. 
vypravěč s odstupem zdůrazňuje víru v autoritu a pravdivost Písma, jeho vlastní příběh však naznačuje, že v samém počátku hledání a stejně tak i v situaci ,aporie“ někdy nezbývá než se obejít bez jeho pomoci. O co jiného se ale podle Augustina může hledání opírat?

Pokud se nyní opět krátce vrátíme k první Menónově otázce, ukazuje se, že v jejím jádru nejde jen o to, jak vůbec začít s hledáním v situaci absence vědění, ale na základnější rovině je třeba se ptát, co umožňuje, aby zkoumání vedlo správným směrem. (Nemusí přitom jít nutně o dosažení cíle - jak ostatně dokládá samotný dialog Menón, v jehož závěru sice hledání značně postoupí, ale samotného výměru ctnosti či zdatnosti se rozmlouvající nakonec nedoberou.) Jinak řečeno, je třeba zamyslet se nad tím, na čem se zakládá optimistický předpoklad, že mínění směřuje k nalézání pravdy. Sókratés je, jak se zdá, přesvědčen, že každá racionální bytost, jestliže hledá systematicky a důsledně - tj. pomocí metody, kterou sám rozvíjí - nakonec postupuje správným směrem, tj. odmítá pomýlená mínění a řídí se jen těmi, která jsou pravdivá. Toto jeho přesvědčení se týká samotné povahy lidské rozumové přirozenosti. Podle některých interpretů však podobné stanovisko nemůže zůstat bez dalšího vysvětlení. Zdůvodněním tohoto Sókratova optimismu má být právě Platónova teorie rozpomínky. ${ }^{45}$ Smyslem zavedení myšlenky anamnésis totiž podle této interpretace není to, že by dávala dostatečnou odpověd na první otázku Menónovy aporie, protože sám fakt, že jsme již kdysi měli vědění ${ }^{46}$ nevysvětluje, odkud se v nás bere schopnost hledat. Ta se rozvíjí právě spolu se sókratovskou metodou tázání (elenchus), která spočívá - velmi zkratkovitě řečeno - v jasné formulaci a následném rožrešení aporií. Když tedy Sókratés tvrdí, že hledání samo je rozpomínání ${ }^{47}$ neznamená to, že by anamnésis nějak nahrazovala elenchus. Myšlenka rozpomínky tvoří spíše implicitní rámec procesu hledání, nebot' zdůvodňuje, proč může být nakonec zdařilé, a v tomto smyslu je metafysickým předpokladem optimistického náhledu na lidskou racionální přirozenost. $^{48}$

45 Srv. G. Fine, Inquiry in the Meno, str. 213. Podle Gail Fineové dokonce zavedení teorie anamnésis není odpovědí na Menónovu aporii jako takovou (k jejímuž rozřešení stačí samotná sókratovská metoda tázání - elenchus), nýbrž má vysvětlit onu základní schopnost lidské rozumové přirozenosti směřovat při takovémto tázání $\mathrm{k}$ pravdě (a nezabřednout $\mathrm{v}$ míněních, která nikam nevedou).

46 Platón, Meno, 81c5-d5.

47 Tamt.

48 Srv. G. Fine, Inquiry in the Meno, str. 213-215. 
Zprvu se tedy zdá, že Augustin zastává přinejmenším v I. knize $V y$ znání - ovšem na základě autority Písma - obdobný epistemický optimismus, jaký je vlastní Sókratovi. Viděli jsme však, že jeho vyprávění tento postoj problematizuje, a proto autor $\mathrm{v} X$. knize zkoumá ještě jiný možný zdroj optimismu hledání, který by - podobně jako u Platóna - vycházel z lidské přirozenosti, aniž by se přitom ale odvolával na anamnésis. $\mathrm{V}$ X. knize bychom proto nenašli žádnou analogii obratu k víre, jakou představila kniha I.

\subsubsection{Problém intencionality}

Myšlenka rozpomínky má být tedy jednou z možných odpovědí na otázku, co zakládá směrodatnost hledání. Jak je tomu ale v Augustinově případě se samotným počátkem hledání? Ukázalo se, že jeho pátrání nemá zprvu jasně stanovený předmět, u nějž by setrvalo; mezi původně hledanou ciceronskou moudrost či blaženost a křest'anského Boha nelze bez dalšího klást rovnítko. ${ }^{49}$ Zacílení celého procesu se tedy stanovuje průběžně a děje se s vědomím toho, že cíl sám není bezezbytku dosažitelný. Pak je ovšem namístě ptát se, z čeho takto nesamožrejmé hledání vychází.

Někteří badatelé se domnívají, že nejhlubší otázkou Menónovy aporie je nakonec problém intencionality: jak vůbec můžeme mít intencionální vztah k něčemu, o čem nemáme vědění ? ${ }^{50}$ Zřejmě platí, že už samo užívání slova „bůh“ nějak předpokládá intencionální vztah k referentu, ale zároveň není vůbec jisté, zda každé užití tohoto slova (včetně plurálu apod.) odkazuje k Bohu, kterého Augustin hledá (a i kdyby tomu tak bylo, je namístě zkoumat, za jakých se to děje podmínek). ${ }^{51}$ Jak by koneckonců mohl Augustin vědět, že Bůh, který je mu hlásán a v nějž věří, je tím Bohem, jejž hledá, jestliže jej dosud nepoznal? ${ }^{52}$ Tato úroveň zkoumání Menónovy aporie se bezprostředně týká otázky předchozí (čím je dáno správné směřování hledání), jde pouze o základnější vrstvu: co umožňuje samu relaci k hledanému?

49 Ke vztahu mezi moudrostí, blažeností a Bohem v cassiciackých dialozích srv. výše, pozn. 3 .

50 Srv. S. Menn, The Desire for God, str. 84.

51 Srv. tamt. Odlišnou pozici patrně zastává J. Brachtendorf, který má za to, že podle X. knihy Vyznání člověk disponuje quasi přirozenou obeznámeností s významem pojmu Bůh. J. Brachtendorf, Die Struktur des menschlichen Geistes nach Augustinus. Selbstreflexion und Erkenntnis Gottes in De Trinitate, Hamburg 2000, str. 112-114.

52 Srv. S. Macdonald, The Paradox of Inquiry, str. 25. 
Augustin častěji opakuje, že hledat Boha můžeme jen tehdy, jestliže jej toužíme poznat. A touha je jistě intencionálním vztahem. Celá otázka se tím ale jen posouvá: zůstává nejasné, jak po Bohu můžeme toužit nebo jej milovat, aniž bychom jej napřed poznali. Proto se Augustin v úvodu X. knihy (ještě před zkoumáním paměti) táže: „Co miluji, když tě miluji? “53 Přinejmenším podle ranějších Augustinových textů, jejichž ozvěna je však ve Vyznáních dosud zřetelná, je lidská touha konstitutivně touhou po Bohu.$^{54}$ Touha či chtění se přitom nevyznačuje pouze tím, že se něčeho domáháme, ale neurčité chtění lze někdy zpětně identifikovat, jestliže došlo svého naplnění ${ }^{55}$ Toto negativní kritérium bychom našli ve známém obratu z úvodního odstavce Vyznání: „Nebot' jsi nás stvořil pro sebe a nepokojné je naše srdce, dokud nespočine v tobě. " ${ }^{56}$ Snad je tedy namístě chápat tento obrat nejen $\mathrm{v}$ jeho rétorické kvalitě, ale jako svého druhu ,technické tvrzení“" které vyjadřuje, oč v celém textu půjde. ${ }^{57}$

Podobné zdůraznění hlubšího neklidu, jenž uvádí duši do pohybu, sotva unikne komukoli, kdo čte Vyznání prizmatem aporie hledání. ${ }^{8}$ Nejde jen o to, že není v moci čehokoli stvořeného tento neklid utišit,

53 Augustin, Confess. X,6,8 / CCL 27,159: quid autem amo, cum te amo? Srv. též: Non dubia, sed certa conscientia, domine, amo te. (tamt., str. 158); dále tamt., X,7,11 / CCL 27,160: Quid ergo amo, cum Deum meum amo? Quis est ille super caput animae meae? Srv. k tomu, co se říká o blaženosti tamt., X,20,29 / CCL 27,170-171: Ubi viderunt, ut amarent eam? ... Neque enim amaremus eam, nisi nossemus. Láska předpokládá jakousi obeznámenost, ale nikoli nutně poznání. K tomuto motivu se vrátíme.

54 Srv. mj. týž, Solil. I,1,2 / CSEL 89,4: Deus, quem amat omne quod potest amare, sive sciens, sive nesciens. Na této tezi staví svou analýzu X. knihy S. Menn (The Desire for God, str. 85) a přirovnává ji k Platónově přesvědčení o tom, že vždy toužíme po skutečném dobru, a nikoli po jeho zdání, tj. i když se chybně domníváme, že X je dobré, to, po čem toužíme, není X, ale cosi, co je skutečně dobré (s odkazem na Platónova Gorgia, 467a8-468e5). Domnívám se nicméně, že tato teze je v případě Augustina problematická, nakolik bychom brali vážně ta místa jeho (především pozdějších) textů, v nichž hovoří o dvojí touze či dvojí lásce. Srv. Augustin, De civ. Dei, XIV,28 / CCL 48,451: Fecerunt itaque civitates duas amores duo, terrenam scilicet amor sui usque ad contemptum Dei, caelestem vero amor Dei usque ad contemptum sui. K tomu srv. L. Karfíková, Jazyk touhy v Augustinových prvních dílech, in: M. Vrabec (vyd.), Touha a žádostivost v dějinách evropské filosofie, Praha 2014, str. 83-116. K této otázce se vracím níže v podkapitole Dva pohledy na povahu touhy.

55 Srv. S. Menn, The Desire for God, str. 85.

56 Augustin, Confess. I,1,1 / CCL 27,1: quia fecisti nos ad te et inquietum est cor nostrum, donec requiescat in te.

57 Srv. S. Menn, The Desire for God, str. 85-86.

58 Srv. též S. Macdonald, The Paradox of Inquiry, str. 24. 
a proto je jedině Bůh skutečným a posledním předmětem touhy. Samu touhu je třeba chápat tak, že ona nemožnost být uspokojena čímkoli jiným je pro ni konstitutivní. ${ }^{59}$ Analogickou myšlenku základní intence zaměřené $\mathrm{k}$ Bohu bychom našli už v Augustinových Hovorech se sebou samým (Soliloquia), kde je řečeno, že ,vše, co je schopno lásky, miluje Boha, at' vědomě, či nevědomky““ ${ }^{60}$ Tato touha, která je zakořeněna v samotné přirozenosti stvořené bytosti, by tedy mohla být Augustinovou odpovědí, jež by ve věci intencionality hledání nahradila platónskou anamnésis. Ale jak může být tato - dosud slepá - touha směrodatná? Jinými slovy: jak můžeme vědět, kde nalezneme naplnění této základní touhy, jestliže jsme je dosud nezažili? (Znamená to, že ten, kdo se - třeba jen na čas - spokojí s jinými cíli hledání, je na tom hưřr než ten, kdo je permanentně nespokojen?) A je skutečně touha podle Augustina ze své přirozenosti takto nerozdělená? Uvidíme, že i na to se pokouší X. kniha Vyznání odpovědět.

\subsection{Jak rozpoznáme, co jsme hledali?}

Zaměřme se ale nejdříve na druhou Menónovu otázku: co by v Augustinem formulované aporii hledání vlastně znamenalo poznání? Nestačí totiž říci, že věříme (nebo máme pravdivé mínění), že jsme na správné cestě k Bohu, a na konci tohoto hledání i nadále zůstávat u stejné víry či mínění, že jsme nalezli, co jsme hledali. Podle převažujících interpretací má platónská anamnésis, jak je představena v dialogu Menón, řešit právě tento problém, totiž jak se z pouhého mínění stává poznání, resp. vědění; rozhodující je tu přitom poukaz na „nabírání vědění v sobě samém“, tj. na rozpoznání čehosi, co vždy již máme či známe. ${ }^{61}$ Jiní autoři naopak zastávají stanovisko, podle nějž se lze v této věci dobře obejít i bez teorie rozpomínky, nebot' k vědění vede samotná sókratovská metoda tázání (elenchus), v ideálním případě provázená rozřešením aporií. ${ }^{62}$ Této spletité otázce, kterou si v reakci na Platóna kladl už Aristotelés a jeho následovníci, se zde nemůžeme věnovat. ${ }^{63}$ At' už je tomu jakkoli, pokud

\footnotetext{
59 Srv. S. Menn, The Desire for God, str. 86.

60 Citováno výše, pozn. 54.

61 Srv. Platón, Meno, 85c6-d8.

62 Srv. G. Fine, Inquiry in the Meno, str. 213 a S. Menn, The Desire for God, str. 83 .
}

63 Srv. k tomu Aristotelés, Met. III,1,995a34-b2. Tuto pasáž uvádí S. Menn, The Desire for God, str. 75 a 82-83. 
se $-\mathrm{v}$ tomto príípadě augustinovští - badatelé na něčem shodují, pak je to přesvědčení, že ačkoli byl Augustin s teorií anamnésis obeznámen, ${ }^{64}$ v době psaní Vyznání toto řešení odmítá, a to nejen v otázce hledání a poznání Boha. Je však třeba dodat, že tam, kde proti platónské teorii rozpomínky výslovně argumentuje ${ }^{65}$ odmítá ji v té její podobě, která předpokládá vědění, jež bylo v minulosti aktualizováno a později (po narození) opět zapomenuto. To však bezpochyby není jediný způsob, jak lze anamnésis chápat. Její odmítnutí tedy nutně neznamená, že by Augustin nepřijal určité aspekty Platónova řešení.

\subsubsection{Poznání věcí samých}

Vyznání se liší od některých dřivějších Augustinových textů tím, že hledání Boha zde nepostupuje přes zkoumání matematických relací nebo jiných neměnných zákonitostí, jimiž se zabývají svobodná umění a jež bývají pro otázku poznání normativní. ${ }^{66}$ Zároveň jsou ale některé rysy přítomnosti věcí samých (res ipsae) v paměti - mezi něž patří vedle poznatků trivia právě čísla a matematické či geometrické vztahy - pro jeho řěení paradoxu hledání ve Vyznáních důležité. $Z$ analýzy paměti věcí samých je také zjevné, co z nauky o anamnésis Augustin odmítá. První učení či poznání těchto věcí samých je zde popsáno takto:

„Odkud a kudy přišly [ty věci] do mé paměti? Nevím, jak se to stalo, nebot' když jsem se jim naučil, neuvěřil jsem jinému srdci, ale rozpoznal jsem je ve svém vlastním a uznal jsem, že jsou pravdivé. ... A když byly vyřčeny, kde a proč jsem je opět poznal a řekl ,Ano, je to pravda,' když ne proto, že už byly v paměti, ale tak vzdálené

64 Srv. Augustin, Solil. II,20,35 / CSEL 89,95; Ep. 7,1,2, vyd. A. Goldbacher, CSEL 34/1, Wien 1895, str. 14, atd. Badatelé mají za to, že Augustin znal Platónova Menóna nejspíš v Ciceronově parafrázi (Cicero, Tusc. disp. I,24,57-58) a možná výlučně z tohoto zdroje. Srv. k tomu L. Karfíková, Anamnesis. Augustin mezi Platonem a Plotinem, Praha 2015, str. 124-125.

65 Augustin se vůči anamnésis vymezuje na více místech, ale argumentačně se s ní vyrovnává zejména v De Trin. XII,15,24 / CCL 50,377-378. K různým možnostem, jak rozumět anamnésis, a k Augustinovu průběžnému vyrovnávání s touto naukou srv. rovněž L. Karfíková, Anamnesis.

66 Takto Augustin postupuje zejm. v De lib. arb. II,8,20-24 / CCL 29,250-253, ale např. i v raných spisech $O$ nesmrtelnosti duše nebo $O$ hudbě, VI. 
a zastrčené - jakoby ve skrytých slujích - že bych je sotva mohl myslet, kdyby nebyly odkryty připomenutím někoho jiného?‘67

Podobně jako v Menónu i zde poznat něco jako pravdivé znamená to již znát, a to vnitřní evidencí, nikoli pouze na základě víry ve svědectví druhého; kritériem takové evidence pak je, že danou věc už máme v paměti a jako takovou ji roz-poznáváme. A podobně jako v Menónu i zde metafora vzdálenosti těchto předmětů poznání, vzdálenosti, která dokonce může sahat tak daleko, že ji lze překlenout jedině s pomocí připomínky druhého, poukazuje na meze individuální vůle či intence a na význam dialogu pro zpřítomnění věcí samých. ${ }^{68}$ Tuto myšlenku lze porovnat s přesvědčením zastávaným Aristotelem, a to právě v kontrapozici vůči Platónově představě učení jako rozpomínání, které se často děje ve filosofickém rozhovoru s druhým. Aristotelés je přesvědčen o tom, že neschopnost vybavit si nějaký poznatek vlastním přičiněním, kvůli níž je nutné upomenutí ze strany druhého, svědčí o tom, že se danou věc od druhého (znovu) učíme. ${ }^{69}$ Vyznání jsou nicméně pozoruhodná tím, že se - navzdory jisté afinitě k Platónovi - důsledně vyhýbají oběma těmto možnostem vycházejícím z tradice: ačkoli totiž Augustin nachází neměnné věci samy „v paměti“, přesto se na rozdíl od Platóna nedomnívá, že si na ně v pravém smyslu „vzpomínáme“. Patrně proto, aby nebyl vázán předpokladem, že jsme tyto věci měli kdysi aktuálně přítomné. S tím souvisí i to, že pro něj res ipsae - třebaže se nacházejí v paměti - nejsou čímsi „minulým“, leda snad tak, že se stávají minulými ,pro nás“, tj. pro naši proměnlivou pozornost, nakolik jsme ji od nich načas odvrátili. ${ }^{70}$ Na rozdíl od Aristotela si ale zároveň nemyslí, že se jim od druhých (znovu) učíme: rozpoznáváme je totiž - v sobě - jako již známé a druzí

67 Srv. týž, Confess. X,10,17 / CCL 27,164: Unde et qua haec intraverunt in memoriam meam? Nescio quomodo; nam cum ea didici, non credidi alieno cordi, sed in meo recognovi et vera esse approbavi... Ibi ergo erant et antequam ea didicissem, sed in memoria non erant. Ubi ergo aut quare, cum dicerentur, agnovi et dixi: ,Ita est, verum est", nisi quia iam erant in memoria, sed tam remota et retrusa quasi in cavis abditioribus, ut, nisi admonente aliquo eruerentur, ea fortasse cogitare non possem?

68 Srv. L. Karfíková, Anamnesis, str. 61-62.

69 Aristotelés, De mem. 452a4-12. Srv. k této otázce Platón, Meno, 85d; Phd. 75e; Philb. 34b-c. Srv. také R. Sorabji, Aristotelés o paměti, přel. M. Pokorný, Praha 1995, str. 66-67.

70 Toto rozlišení najdeme již v raném Augustinově dopisu Nebridiovi (Ep. 7,1,2 / CSEL 34,1,13-14). 
nám tyto obsahy nanejvýš ,,připomínají“ ${ }^{71}$ Augustin tedy (přinejmenším ve Vyznáních) v souvislosti s inteligibilními předměty nikdy neřekne, že si na ně „vzpomíná“ (s výjimkou pasáže, kde hovoří o vzpomínání na zpřítomnění nějaké znalosti v čase).$^{72}$ Přesto je myšlenka pravdivého poznání jakožto rozpoznání něčeho již známého pro Augustina zrejejmě natolik zásadní, že „umist'uje“ dokonce i trvale přítomné (tj. vlastně neměnné) věci samy „do paměti“ ${ }^{73}$ Proč je pro něj toto kritérium (znovu) rozpoznání tak důležité? Nabízejí se převážně negativní odpovědi: roz-poznání se liší jak od našich obrazných představ (phantasmata) coby výtvorů něčeho nového $\mathrm{z}$ toho, co již známe ${ }^{74}$ tak od víry opírající se o svědectví druhého. Hlavní důraz je tedy kladen na vnitřní evidenci, která je snad v něčem analogická vnitřní evidenci zřetelné vzpomínky na nedávno minulou vlastní zkušenost. ${ }^{75}$ Věci samy si tedy ani nevymýšlíme (v čase nelze vytvářet něco, co samo časovou povahu nemá), ani v ně nevěříme, máme-li je doopravdy poznat; proto je nikdy nepoznáváme jako nové. A jelikož zároveň nejsou minulé (nýbrž nanejvýš minulé „pro nás“), nemůžeme se na ně v případě prvního učení rozpomínat. Ve srovnání s platónským užitím, které Augustin bezpochyby znal, se tedy ve Vyznáních rozumí ,rozpomínáním“ výhradně zpřítomnění něčeho, co pro nás bylo $\mathrm{v}$ empirické minulosti aktuálně prrítomné. Jestliže si naproti tomu zpř́ítomňujeme cosi, co je pro nás latentně přítomno stále, co

71 Tento problém je zevrubně pojednán v Augustinově dialogu $O$ učiteli $(D e$ magistro).

72 Srv. Augustin, Confess. X,13,20 / CCL 27,165.

73 Srv. G. O’Daly, Remembering and Forgetting in Augustine, „Confessions “ X, in: týž (vyd.), Platonism Pagan and Christian, Aldershot 2001, str. 35.

74 Rozdíl mezi phantasia a phantasma se ve Vyznáních neobjevuje přímo v souvislosti s epistemologickým zkoumáním (srv. Augustin, Confess. III,6,10 / CCL 27,32). Jinde se nicméně opakovaně pojmově odlišuje phantasia něčeho pro nás dříve př́ítomného, co existovalo nebo ještě existuje (například otce nebo Kartága), a phantasma čehosi, co si můžeme jen představit pomocí obměňování vlastních fantasií a co bud' nikdy neexistovalo, nebo jsme se s tím nesetkali, takže si to vykreslujeme na základě vyprávění druhých (například děda nebo Alexandrii). Srv. např. týž, De mus. VI,11,32, vyd. M. Jacobsson, Studia Latina Stockholmiensia (= SLS), 47, Stockholm 2002, str. 68-70; De Trin. VIII,6,9 / CCL 50,281-282; Ep. 7,2,4 / CSEL 34,1,15-16. K tomu L. Karfíková, Fantazie a pamět'v Augustinově korespondenci s Nebridiem, in: táž, Filosofie Augustinova mládí, str. 82-109.

75 Srv. Augustin, Confess. X,19,28 / CCL 27,170: „Nezačínáme totiž v to jméno věřit jako v nové, nýbrž vzpomínáme si..." (Non enim quasi novum credimus, sed recordantes...). Ovšem vzhledem k tomu, jak je augustinovská epistemologie spojena s jeho ontologií, je třeba mít na paměti, že ani sebepřesnější vzpomínka na minulou zkušenost nemá větší přesvědčivost než evidence věcí samých. 
jsme však dosud aktuálně nenahlíželi, nejedná se o vzpomínání na cosi zapomenutého, třebaže to nacházíme „v paměti“ a třebaže nám to druzí mohou ,přripomenout“..$^{76}$

Jak nám ale někdo může připomenout věci samy, když jsme je jako takové nikdy neměli aktuálně přítomné? Zdá se, že Augustin chápe připomínání - a podobně i samostatné učení - především jako pohyb, jenž vede k soustředění pozornosti na obsahy vlastní mysli: pamět' latentně obsahuje mnoho zákonitostí, ale ponechána sama sobě uchovává své obsahy neutříděné, a dokonce i to, co už bylo jednou myšlením shromážděno a uspořádáno, má tendenci se v tomto médiu po čase opět rozptýlit a od sebe vzdálit. ${ }^{77}$ Jakkoli v sobě tedy pamět' podivuhodným zpơsobem drží neměnné věci samy, přece není s to - coby schopnost těkavých tvorů - trvale $\mathrm{v}$ sobě podržovat $\mathrm{v}$ jakémsi názorném zpřítomnění vnitřní obsah i širší souvislosti těchto věcí (a to ani potom, co je myšlení nahlédne). Věci samy podle Augustina sice nenáležejí ,ř́íši idejí“ a jsou takříkajíc na dosah ruky ve vlastní paměti, ta je však sama proměnlivá, a proto zůstává moment rozpoznání korelátem schopnosti soustředit pozornost, která je vždycky jen přechodná. Spojitost schopnosti myslet (cogitare) se soustředěním pozornosti (spolu s důrazem na limity této schopnosti) má určitý význam i pro naše téma.

76 Už ve svých raných spisech Augustin zmiňuje úplné zapomenutí např. na časné dětství, srv. Solil. II,20,34 / CSEL 89,94; De Trin. XIV,5,8 / CCL 50,430. Tento motiv se častěji vrací i v první knize Vyznání (Confess. I,6,7-8; 10; 7,11-12 / CCL 27,4-8). V některých dílech Augustin dokonce zapomenutí na prvotní období života přirovnává k prvnímu věku lidstva zaplaveného potopou, srv. De civ. Dei, XVI,43 / CCL 48,550; De Gen. Manich. I,23,35, vyd. D. Weber, CSEL 91, Wien 1998, str. 104. Od této možnosti úplného zapomenutí ale odlišuje zapomenutí, které je pouze zdánlivé, protože se týká předmětů paměti, na které v pravém smyslu zapomenout nelze. Tak se podle spisu $O$ nesmrtelnosti duše skrývají v duši pravdivé rozumové zákonitosti, ,jakkoli se snad zdá, že v ní pro její nevědomost či zapomnění ani nejsou nebo že je ztratila“" (De immort. animae, 4,6, vyd. W. Hörmann, CSEL 89, Wien 1986, str. 107; český překlad cit. podle: Aurelius Augustinus, $O$ nesmrtelnosti duše, přel. L. Karfíková, Praha 2013, str. 43). Zapomínání v této souvislosti znamená spíše bezděčné odhlížení od určitých duševních obsahů, případně také kontrast k jejich náhlému vyvstání. Pravdivé věci ale v sobě duše vždy již má, a proto je nachází, a nikoli tvoří: „Nacházet přitom není totéž co tvořit či plodit, jinak by naše duše svým nacházením v čase plodila věčné věci.“ (Srv. tamt.)

77 Srv. Augustin, Confess. X,11,18 / CCL 27,164. 


\subsubsection{Poznání Boha}

Vrat'me se proto k otázce, co by pro Augustina mohlo znamenat poznání Boha. Není pochyb, že „theologická verze paradoxu hledáni“"78 je aporií zvláštního druhu. Přinejmenším se nezdá, že by Augustin ve Vyznáních hledal Boha podobně, jako se otrok v Menónu „rozpomíná“ na řešení geometrické úlohy. A když si Augustin klade sókratovskou otázku „kdo jsi?““ (quid es?), znamená to, že se pídí po poznání, jehož kritériem je předložení definice? Stěží. Na druhou stranu mu ale i zde - podobně jako v případě „věcí samých“ - záleží na rozdílu mezi vírou (jako analogií mínění) a vnitřním nahlédnutím; toto nahlédnutí však, jak ještě uvidíme ${ }^{79}$ nemůže vysvětlit stejným způsobem jako u věcí samých: prvotní poznání Boha je čímsi novým. ${ }^{80}$ Zároveň je pro Augustina zásadní, aby poznání nezaměnil za pouhé výtvory fantasie. Proto mu snad zpočátku půjde především o to, aby odlišil křest'anského Boha od jiných bohů (manichejské představy nevyjímaje).

Zdá se, že podobné očištění myšlenek vztahujících se k výrazu „bůh“ není možné, dokud nebude vysvětlena řada nejasností, na které mj. právě manichejci neměli žádnou odpověd’. ${ }^{81}$ Pak by bylo možným kritériem poznání - na rozdíl od ulpívání na „fantasmatech“, jimiž manichejství oplývalo - samotné rozřešení aporií, které Augustin ve Vyznáních formuluje (přičemž jeho životopis ukazuje i důsledky těchto ,scestí“) ${ }^{82}$ Hned na počátku I. knihy je to kupř. paradox Boží všudypř́tomnosti: jestliže je Bůh přítomný všude, jak můžeme být my sami nepřítomni jemu,

78 Srv. G. B. Matthews, Augustine on the Mind's Search for Itself, str. 415 (citováno výše, pozn. 11).

79 Srv. níže úvod části Hledání blaženého života.

80 Srv. Augustin, Confess. X,27,38 / CCL 27,175: Sero te amavi, pulchritudo tam antiqua et tam nova, sero te amavi! Augustin netvrdí, tak jako v případě věcí samých, že by měl Boha v paměti.

81 Toto „zadání“ přitom, jak se zdá, pokračuje i poté, co Augustin Boha již nalezl, jak je to vidět v XI. knize, kde exegeze knihy Genesis spolu s úvahami o čase, přesněji řečeno o vztahu věčnosti a času, uvozuje pokus ukázat pomýlenost předpokladů manichejské otázky po tom, co dělal Bůh předtím, než stvořil nebe a zemi.

82 Srv. tamt., III,6,10 / CCL 27,32: Quanto ergo longe es a phantasmatis illis meis, phantasmatis corporum, quae omnino non sunt! Quibus certiores sunt phantasiae corporum eorum, quae sunt, et eis certiora corpora, quae tamen non es. Oproti tomu srv. tamt., VII,17,23 / CCL 27,107: et mirabar, quod iam te amabam, non pro te phantasma. 
pokud zároveň tuto absenci předpokládáme, když jej hledáme ${ }^{83}$ Později v VII. knize se tato otázka opět vrací a spolu s ní se objevuje problém původu zla: jak může být Bůh dobrý, všeprostupující, všemohoucí, a současně v jeho stvoření existovat zlo? ${ }^{84}$ Jakýsi bod obratu v Augustinově hledání představuje právě kniha VII, kde jsou nejprve dosavadní aporie znovu připomenuty včetně jejich kořene, jenž tkví v neschopnosti myslet neviditelnou (tj. netělesnou) substanci, a z něj plynoucí vidiny boha coby jakéhosi prostorného nic (spatiosum nihil). ${ }^{85}$ Zajímavé je, že první „poznání“ Boha je tu popsáno jako svého druhu vedení do aporie, v němž se zároveň otevírá průzor k tomu, co má být nalezeno: „A když jsem tě poprvé poznal (cum te primum cognovi), ujal ses mě, abych uviděl, že existuje cosi, co bych vidět mohl, ale co vidět dosud nejsem schopen.“ ${ }^{86}$ Ze „změti vzájemně si odporujících smyšlenek“"87 se Augustin vysvobodí teprve postupným chápáním ,jiné než tělesné nekonečnosti“ “ ${ }^{88}$ které vrcholí tzv. novoplatónským výstupem, jenž s sebou přináší i nahlédnutí duchovní substance. ${ }^{89}$

83 Srv. tamt., I,2,2 - 3,3 / CCL 27,1-2. Srv. k tomu S. Menn, The Desire for God, str. 80.

84 Srv. Augustin, Confess. VII,4,6; 5,7 / CCL 27,95; 96-97, kde Augustin vzpomíná na své tázání po původu zla (ztotožněného s látkou) a po důvodu jeho rozšrírení ve stvořeném světě. A zanedlouho (VII,16,22 / CCL 27,106) formuluje i určitou odpověd’, podle níž zlo spočívá v odvrácenosti vůle od Boha.

85 Srv. tamt., VII,1,1 / CCL 27,93: cogitare aliquid substantias nisi tale non poteram, quale per hos oculos videri solet.

86 Tamt., VII,10,16 / CCL 27,103: Et cum te primum cognovi, tu assumpsisti me, ut viderem esse, quod viderem, et nondum me esse, qui viderem.

87 Tamt., VII,17,23 / CCL 27,107: subtrahens se contradicentibus turbis phantasmatum...

88 Tamt., VII,14,20-15,21 / CCL 27,106.

89 Tamt., VII,17,23 / CCL 27,107. K Augustinovým počátečním obtížím pojmout myšlením duchovní podstatu srv. tamt., V,10,19 / CCL 27,68: Et quoniam cum de Deo meo cogitare vellem, cogitare nisi moles corporum non noveram - neque enim videbatur mihi esse quidquam, quod tale non esset - ea maxima et prope sola causa erat inevitabilis erroris mei. A dále tamt., V,14,25 / CCL 27,71: „Kdybych byl dovedl myslet duchovní podstatu, rázem by byla všechna ta nastrojená osidla (machinamenta) [manichejců] rozpletena a odmrštěna z mého ducha - ale nedovedl jsem to." (Quod si possem spiritalem substantiam cogitare, statim machinamenta illa omnia soluerentur et abicerentur ex animo meo: sed non poteram.) Srv. tamt., VI,3,4 / CCL 27,76. Pokud jde o nerozumění podstatě Boha (ač zde není výslovně řeč o její duchovní povaze), srv. tamt., VI,5,7-8 / CCL 27,77-78. K významu myšlenky netělesné substance (resp. imateriální povahy duše a Boha), kterou Augustin jako první v západní církvi jasně formuloval, srv. R. Teske, Paradoxes of Time in Saint Augustine, Milwaukee 1996, str. 18. 
Není vyloučeno, že právě tento moment znamenal pro autora Vyznání první poznání Boha. Nasvědčuje tomu retrospektivní poznámka na začátku VIII. knihy, kde Augustin ještě před vyprávěním o milánském obrácení sděluje, že Boha už nalezl.$^{90}$ Zároveň se v VII. knize po tomto novoplatónském nahlédnutí podivuje nad tím, že již miluje Boha, a ne nějaký přelud, aby o něco dále dodal, že si od té doby uchovával na Boha vzpomínku. ${ }^{91}$

Vlastní popis náhledu netělesné substance je analogií (novo)platónských podobenství o putování duše do inteligibilní oblasti. ${ }^{92}$ Augustinův duchovní výstup k Bohu v knize VII je vylíčen jako aktivita, kterou v posledních krocích provádí rozumová schopnost (potentia ratiocionans) a nakonec v jakémsi záchvěvu (in ictu trepidantis aspectus) také nahlížení (intellegentia) ${ }^{93}$ Podobně je i ostijský rozhovor v knize IX představen jako zkušenost, která se uskutečňuje cestou myšlení (cogitatio) a nastává v krátkém okamžiku nahlédnutí (momentum intellegentiae).$^{94}$ Těsnou paralelou obou těchto líčení jsou podle většinového názoru badatelů Plótinovy Enneady. ${ }^{95}$ Ponecháme-li stranou bohatý rejstřík podobností a nepodobností, je tento popis, v němž se dospívá k nejvyššímu poznání jako k výsledku pohybu od nižších schopností duše k rozumové úvaze či myšlení a vposled k nahlédnutí, pro Augustina - přinejmenším v jeho raných textech - typický. ${ }^{96}$ Méně obvyklý je snad důraz na okolnost, že pravé poznání trvá pouhý okamžik..$^{97}$

90 Srv. Augustin, Confess. VIII,1,2 / CCL 27,114: At ego iam non eram in illa vanitate; transcenderam eam et contestante universa creatura inveneram te creatorem nostrum et verbum tuum apod te Deum tecumque unum Deum, per quod creasti omnia. Milánské obrácení najdeme tamt., VIII,12,29 / CCL 27,131.

91 Tamt., VII,17,23 / CCL 27,107: Et mirabar, quod iam te amabam, non pro te phantasma...; Sed mecum erat memoria tui...

92 Srv. Platón, Phaedr. 249b6-c4; Resp. VI,508d4-e6; VI,511b6-c2 ad.; Plótinos, např. Enn. V,3(49),4,7-15.

93 Augustin, Confess., VII,17,23 / CCL 27,107.

94 Srv. tamt., IX,10,25 / CCL 27,148.

95 Srv. Plótinos, Enn. V,1,11, resp. I,6,7. Ke vztahu Augustina a Plótina, zejm. pokud jde o nauku o rozpomínce, srv. L. Karfíková, Anamnesis.

96 Jakýsi předobraz obou výstupů z Vyznání lze najít například v Augustinově raném textu $O$ velikosti duše - srv. De quant. an. I,33,70-76, vyd. W. Hörmann, CSEL 89, Wien 1986, str. 217-225. Našli bychom zde ovšem i podstatné rozdíly. K tomu srv. J. J. O’Donnell, Augustine. Confessions, II, str. 456.

97 Například v pasáži ze spisu $O$ velikosti duše uvedené v předchozí poznámce je podobná prchavost poznání př́íznakem toho, že duše má zapotřebí dalšího očištování. Skutečného zření a spočívání (mansio) v radostné kontemplaci pravdy 
Když Augustin v knihách VII a IX vypráví, jak se na chvíli ocitl v Boží přítomnosti, hned dodává, že v ní nedokáže setrvat. I po nejzdařilejších pokusech tohoto druhu následuje návrat do každodenního, tělesností obtíženého života, k pouhému ,ševelení našich úst“ (jako tomu bylo v Ostii); zůstává jen „drahá vzpomínka“. 98 Tyto zkušenosti nejsou ani platonikům neznámé. Augustin ale zřejmě nechce jen říci, že si uvědomuje nepoznatelnost toho, koho hledá (připomeňme zde známou parafrázi „Bůh se lépe poznává nepoznáním“, Deus melius scitur nesciendo, ze spisu $O$ pořádku, která je patrně ozvěnou jedné z Porfyriových Sentencî). ${ }^{99}$ Spíše poukazuje na specifičnost cíle svého zkoumání, v němž nakonec nejde jen o poznání, ale také o možnost spočinout v Boží přítomnosti. Tím by se mělo - alespoň podle jeho slov z Vyznání - toto zkoumání od novoplatoniků odlišovat:

„Rozlišil jsem a rozeznal, jaký je rozdíl mezi radostným očekáváním a vyznáním, mezi těmi, kdo vidí, kam jít, aniž by věděli kudy, a cestou vedoucí k blažené vlasti (beatifica patria), ${ }^{100}$ kterou máme nejen uzřít, ale také v ní přebývat."101

Ve svých ranějších textech Augustin připouští, že by mohlo být takové „přebývání“ nebo „spočívání“ (mansio) vznešeným duším přístupné už

pak dosahují podle Augustina jen velké a s nikým neporovnatelné duše. Srv. tamt., I,33,75-76 / CSEL 89,223.

98 Srv. týž, Confess. X,40,65 / CCL 27,191, dále IX,10,24 / CCL 27,148: remeavimus ad strepitum oris nostri a VII,17,23 / CCL 27,107: amantem memoriam.

99 Srv. týž, De ord. II,16,44 / CCL 29,131: quisquis ergo ista nesciens, non dico de summo illo Deo, qui scitur melius nesciendo, sed de anima ipsa sua quaerere ac disputare voluerit, tantum errabit quantum errari plurimum potest a Porfyrios, Sent. intelleg. 25: „O tom, co přesahuje Intelekt, se sice mnoho vypovídá na základě intelektuálního nahlížení, nazírá se však ne-nahlížením, které je silnější než nahlížení. Podobně se o spícím mnoho vypovídá za bdění, poznání a uchopení však lze dojít jen spaním. Podobné je totiž poznáváno podobným, protože veškeré poznání je připodobnění poznávanému." Český překlad cit. podle: Porfyrios, Jak vystoupit do inteligibilního světa, přel. L. Karfíková, Praha 2017, str. 111.

100 Srv. Plótinos, Enn. I,6,8,16-27. (Srv. také Augustin, De beata vita, 1,2 / CCL 29,65.)

101 Srv. týž, Confess. VII,20,26 / CCL 27,110: discernerem atque distinguerem, quid interesset inter praesumptionem et confessionem, inter videntes, quo eundum sit, nec videntes, qua, et viam ducentem ad beatificam patriam non tantum cernendam sed et habitandam. Ponechávám stranou otázku, zda je tomu u platoniků skutečně tak, jak to zde Augustin chápe. 
v tomto životě. ${ }^{102}$ Ve Vyznáních pak vyjadřuje jistotu, že blažený život „nějakým způsobem máme“, jen neví, jakým. Dále pak rozlišuje (podobně jako v raném dialogu $O$ blaženém životě) mezi lidmi, kteří jsou blažení skutečně (in re), lidmi, kteří jsou blažení v naději (in spe), a těmi, kdo nejsou blažení ani ve skutečnosti, ani v naději (nec re nec spe). ${ }^{103}$ Zdá se tedy, že i zde se Augustin chce odlišit od platónských souputníků svým zájmem o blažený život jako o stav, který charakterizuje existenci toho, kdo tento život má či hledá. ${ }^{104}$

Když si tedy Augustin na úvod svého pátrání v knize X klade zmíněnou otázku: „Co miluji, když tě miluji?““, ${ }^{105}$ sám si různými poetickými obrazy odpovídá, že hledá naplnění, které by bylo trvalé. ${ }^{106}$ Příčinou absence tohoto naplnění je ale stav toho, kdo hledá („koho naplňuješ, toho pozvedáš, a protože já tebou naplněn nejsem, jsem ted’ sám sobě přítěží $\left.{ }^{\prime \prime}\right){ }^{107}$ Proto Augustin už v VII. knize nezapomíná zdůraznit, že (novoplatónské) poznání duchovní substance vyžaduje doplnění, které z něj teprve učiní poznání křest'anského Boha. To podle něj není možné bez víry v Krista (coby oné „,cesty“ k blažené vlasti) a bez katharsis ve specificky křest’anském smyslu, která obnáší celkovou proměnu poznávajícího. ${ }^{108}$ Jestliže je tedy pro touhu po Bohu, jak už bylo řečeno, konstitutivní, že nemůže dojít naplnění jinde než v něm, pak nejenže jeho poznání předpokládá změnu na straně poznávajícího, ale zdá se, že tato změna má být zároveň projevem tohoto pozná(vá)ní. (Augustin si proto v X. knize neklade pouze otázku, na čem se zakládá možnost intencionálního vztahu k tomu, co hledáme, a důvěra, že toto pátrání povede správným směrem, ale stejně tak v její druhé polovině zevrubně líčí, jak

102 Srv. týž, De quant. an. I,33,75-76 / CSEL 89,223 - viz pozn. 96. Srv. také týž, De beata vita - viz pozn. 3 .

103 Srv. týž, Confess. X,20,29 / CCL 27,170.

$104 \mathrm{O}$ tom se však v samotných Vyznáních nedozvíme mnoho. V tomto smyslu nicméně hovoří už dialog O blaženém životě, kde je blaženost charakterizována jako Deum habere. Týž, De beata vita, 2,11; 3,19 / CCL 29,72; 76.

105 Týž, Confess. X,6,8 / CCL 27,159 (viz výše, pozn. 53).

106 Tamt.: ubi sonat, quod non rapit tempus... atd.

107 Tamt., X,28,39 / CCL 27,175: Nunc autem quoniam quem tu imples, sublevas eum, quoniam tui plenus non sum, oneri mihi sum.

108 Srv. tamt., VII,18,24-21,27 / CCL 27,108-112. 
je možné, že v situaci, kdy všichni mají předpoklady nalézt, co hledají, a někteří to dokonce už našli, přesto tápou. $)^{109}$

\subsubsection{Problém rozpoznání}

Všechny tyto úvahy staví do zvláštního světla otázku, co by v případě Boha znamenalo skutečné poznání: proč se Augustin v X. knize vrací ke svému tázání z I. knihy, totiž „kde“ má Boha hledat, ${ }^{110}$ když už předtím vyprávěl o novoplatónském výstupu, o své konverzi i o podivuhodném vidění (či spíše slyšení), které zažil při rozhovoru s matkou v Ostii? A proč se ke své původní otázce vrací poté, co zevrubně prozkoumal všelijaké odlehlé komnaty paměti a současně vyjádřil určité rozčarování nad její nezbadatelnou hloubkou? Zdá se, že tato vnitřní neprůhlednost, v níž nelze obsáhnout ani sebe sama, v něm vyvolává touhu hledat Boha „Za“ schopností paměti. Avšak jeho pokus překročit pamět' (srv. transibo et memoriam) - vyjádřený celkem pětkrát ${ }^{111}$ - naráží na zásadní pochybnost: „Jestliže tě nacházím mimo svou pamět', nepamatuji si na tebe. A jak tě najdu, když si na tebe nepamatuji?"112 Augustin zde zjevně evokuje svou vstupní otázku jako určitou variantu Menónovy aporie, kterou však tentokrát výslovně spojuje s hledáním, jež má oporu v paměti. Pokusme se sledovat, $\mathrm{v}$ jakých krocích při této reformulaci postupuje.

Výchozí pochybnost jej zprvu vede k expozici dvou př́íkladů, a sice ztraceného penízu a rozpomínání se na jméno. První z nich je inspirován evangelijním podobenstvím ( $L 15,8 \mathrm{n})$ : „Žena přece ztratila drachmu a hledala ji se svítilnou - kdyby si na ni nepamatovala, nenašla by ji. A když ji našla, jak by poznala, že je to ona, kdyby si na ni nepamatovala?“"113 Menónův problém nemožnosti hledání a rozpoznání hledaného při absenci poznání je tu převeden na rovinu paměti: abychom něco

109 Tento motiv není neznámý ani platonikům. Jeho křest’anské podobě se Augustin - v rámci Vyznání - věnuje především v VIII. knize a ve druhé polovině X. knihy. Zde se mu však budeme věnovat jen v souvislosti s první částí X. knihy, kde má konstitutivní význam, ač mu není věnováno tolik prostoru.

110 Srv. tamt., X,17,26 / CCL 27,168-169.

111 Tamt.

112 Tamt., X,17,26 / CCL 27,169: Si praeter memoriam meam te invenio, immemor tui sum. Et quomodo iam inveniam te, si memor non sum tui?

113 Tamt., X,18,27 / CCL 27,169: Perdiderat enim mulier drachmam et quaesivit eam cum lucerna et, nisi memor eius esset, non inveniret eam. Cum enim esset inventa, unde sciret, utrum ipsa esset, si memor eius non esset? 
vůbec mohli hledat, musíme si pamatovat, co hledáme (nebo si alespoň pamatovat, že to máme hledat), a stejně tak si to musíme pamatovat, máme-li rozpoznat, že jsme to našli: „Kdybych si na to nepamatoval, at' už by to bylo cokoliv, i kdyby to bylo přede mnou, nenašel bych to, protože bych to nepoznal." "114 Tuto výchozí ilustraci Augustin rozvíjí ve druhém př́kladu tak, že ji dále zvnitřňuje: „A co když něco ztratí samotná pamět'? Tak to je, když zapomínáme a hledáme, abychom si vzpomněli. A kde jinde hledáme než v samotné paměti?" ${ }^{115}$ Nevyřčeně zde přitom navazuje na již dřive nedořešenou otázku, kterou přerušil své zkoumání paměti: jak si můžeme pamatovat zapomnění, „které zasypává to, co jsme si zapamatovali“"? ${ }^{116}$ Nějak si jej totiž pamatujeme (tj. víme o něm), jen není jasné jak, když zapomenutí je přece zbaveností paměti (privatio memoriae). ${ }^{117}$ Také v př́padě hledání zapomenutého jména člověka, kterého známe, musíme vědět o svém zapomenutí ( $\mathrm{tj}$. vlastně vědět, že jsme s ním nějaké jméno měli spojené, ačkoli si na něj nyní nevzpomínáme). ${ }^{118}$ Samotné rozpoznání zároveň předpokládá, že si hledané pamatujeme nějak podstatněji: jméno onoho člověka se nesmí z mysli vytratit zcela, abychom mezi jmény, která se nám nabízejí, mohli poznat to správné. Hledáme a rozpoznáváme tedy jen to, na co jsme nezapomněli beze zbytku: „na co jsme zapomněli úplně, to tedy ani nebudeme moci hledat jako ztracené“. ${ }^{119}$ Rozhodující roli zde má částečné pamatování a částečné zapomenutí, které má implicite více vrstev. Bezprostředně po tomto závěru si Augustin opět klade otázku, jak má hledat Boha, a odpovídá si, že snad jako blažený život. Uvidíme, že také v tomto př́ípadě pro něj bude rozhodující, zda a jakým způsobem je blažený život v paměti. ${ }^{120}$

Proč tedy Augustin hledá Boha v paměti? Vždyt' první poznání Boha popsané v knize VII (resp. IX) nebylo v žádném ohledu výsledkem

114 Tamt.: Cuius nisi memor essem, quidquid illud esset, etiamsi mihi offerretur, non invenirem, quia non agnoscerem.

115 Tamt., X,19,28 / CCL 27,169-170: Cum ipsa memoria perdit aliquid, sicut fit, cum obliviscimur et quaerimus, ut recordemur, ubi tandem quaerimus nisi in ipsa memoria?

116 Tamt., X,16,25 / CCL 27,168.

117 Srv. tamt., X,16,24 / CCL 27,167.

118 Augustin přitom zčásti řeší problém paměti zapomenutí tím, že se přestane zabývat zapomenutím jako takovým, ale soustředí se na zapomenutou věc.

119 Tamt., X,19,28 / CCL 27,170: Hoc ergo nec amissum quaerere poterimus, quod omnino obliti fuerimus.

120 Tamt., X,20,29 / CCL 27,171: satago, utrum in memoria sit ... quaero, utrum in memoria sit beata vita. 
průzkumu paměti, nýbrž šlo o zkušenost, k níž jej přivedla rozumová schopnost či myšlení a poté nahlížení. Ve svých ranějších spisech navíc Augustin pokládá pamět' - zcela v plótinovském duchu ${ }^{121}$ - za nižší schopnost duše, než je myšlení, a také v samotné X. knize touží pustit se ve svém pátrání i za hranice paměti. Má snad na mysli jen jakýsi návrat k minulému poznání, od nějž odvrátil pozornost a nyní si jej chce znovu zpřítomnit? Tímto směrem jako by mírily Augustinovy př́íklady $\mathrm{s}$ drachmou a jménem, $\mathrm{v}$ nichž je předmětem hledání cosi ztraceného nebo zapomenutého. Proč se ale Augustin poté, co v X. knize pracně vyložil, v jakém smyslu můžeme mít v paměti i „věci samy“, které jsme dřive nikdy aktuálně nepoznávali, vrací k příkladům evokujícím problematiku vzpomínání na cosi minulého? Proč neužívá pro případ hledání Boha analogický postup, jaký vyložil v souvislosti s res ipsae (jenž by navíc lépe korespondoval s jeho vyprávěním o duchovních výstupech k Bohu)? A v neposlední řadě: proč Augustin v X. knize hledá Boha právě v paměti, třebaže jej tam při prvním poznání nenalezl a třebaže jej tam - jak uvidíme - nakonec ani nenajde?

V následujícím se pokusím ukázat, že Augustinovo hledání Boha v paměti nijak nepopisuje zkušenost návratu, ale klade si hlubší otázku: zda existuje nějaké předchůdné poznání, které by toto hledání vůbec umožňovalo. Tím zároveň vychází najevo těsná souvislost obou částí Menónovy aporie. Nebot' touha jakožto příčina, která - na rovině přirozenosti lidské duše - působí, že hledání vůbec začne, má za svůj předmět (zprvu implicitní) obsah paměti, který je zároveň - na epistemické rovině - vodítkem k rozpoznání hledaného (jako něčeho v jistém ohledu už známého). Augustin se k reformulaci této aporie nikoli náhodou vrací až poté, co vyložil, jakým způsobem jsou v paměti různé typy obsahů. Domnívám se, že jejich analýzu potřebuje k tomu, aby co nejpřesněji filosofickými prostředky popsal, jakou povahu má toto implicitní ,předchůdné poznání“, jemuž obvykle nevěnujeme pozornost. ${ }^{122}$ Hledání Boha v paměti

121 Srv. Plótinos, Enn. IV,3,25 - 4,8; 6,3. Srv. k tomu E. Bréhier, La philosophie de Plotin, Paris 1928, str. 71-75; H. J. Blumenthal, Plotinus' Psychology. His Doctrines of the Embodied Soul, Hague 1971, str. 80-99; L. Brisson, La place de la mémoire dans la psychologie plotinienne, in: Études platoniciennes, 3, 2006, str. 13-27; R. A. H. King, Aristotle and Plotinus on Memory, Berlin - New York 2009.

122 O tomto ,předchůdném poznání“ (Vorwissen) uvažuje v souvislosti s X. knihou Vyznání J. Brachtendorf (Die Struktur, str. 42-43 a str. 112-115). Nezdá se mi ale, že by toto předchůdné poznání spočívalo v jakémsi předběžném rozumění pojmu „Bůh“ (str. 43; 114). K tomu srv. níže podkapitoly Gaudium de veritate a především Spojité obsahy paměti. 
by proto nemělo být zaměňováno s popisem nahlížení Boha v knize VII a IX, třebaže úvodní figura X. knihy, ve které se Augustin dotazuje stvoření na jeho Stvořitele (srv. „A co to je?“ - Et quid est hoc?), ${ }^{123}$ oba dříve popsané duchovní výstupy k Bohu evokuje. Poznání ve smyslu nahlížení je patrně přístupné jen nemnohým a předpokládá předchozí očištění. Smyslem zkoumání X. knihy je naproti tomu explikace přirozeného předporozumění, které je vlastní všem lidským bytostem, které zakládá intencionalitu hledání a které nakonec také umožňuje roz-poznání popsané v duchovních výstupech VII. a IX. knihy. ${ }^{124}$

\section{Hledání blaženého života}

Augustin se tedy v X. knize ptá, jak je možné začít hledat v situaci, kdy jsme Boha dosud nepoznali, tj. v situaci, kdy jej nemáme ve své paměti. Říká zde sice, že od doby, kdy Boha poznal, nezapomněl na něj. ${ }^{125}$ Neříká však, že by Bůh byl v paměti odevždy, tak jako jsou v ní přítomny inteligibilní věci samy. Naopak, autor Vyznání po usilovném průzkumu paměti, jehož hlavním účelem bylo hledání Boha, konstatuje, že Bůh v paměti zprvu nebyl: „Kde jsem tě tedy našel, abych tě poznal? Ty jsi totiž v mé paměti nebyl předtím, než jsem tě poznal.“126 Jakési vodítko k poznání Boha tu ale Augustin přece nachází. O tomto implicitním poznání v prvním přiblížení uvažuje jako o „vzpomínce“ na blažený život nebo jako o zastřené obeznámenosti s blažeností, kterou máme - neznámým způsobem - v paměti. ${ }^{127}$ Někteří vykladači proto ve svých analýzách tohoto místa tíhnou k těsnému spojování Boha a blaženého života. ${ }^{128} \mathrm{~V}$ tomto

123 Augustin, Confess. X,6,9 / CCL 27,159 (viz výše, pozn. 28).

124 Jak to trefně vyjadřuje J. Brachtendorf, Die Struktur, str. 115: „Nahlížení Boha proměňuje víru v poznání, ale samo rozpoznání Boha v tomto nahlížení je možné jen na základě implicitního poznání toho, co je s vírou hledáno a co je v nahlížení také nalezeno.“

125 Augustin, Confess. X,24,35 / CCL 27,174.

126 Tamt., X,26,37 / CCL 27,174-175: Neque enim iam eras in memoria mea, priusquam te discerem.

127 Srv. tamt., X,20,29 / CCL 27,171. Otázka původu této vzpomínky zde přitom zůstává záměrně otevřená.

128 Takto uvažují oba citovaní autoři, kteří se zabývají menónovskou aporií ve Vyznáních, X. Srv. S. Macdonald, The Paradox of Inquiry, str. 30. Srv. též S. Menn, The Desire for God, str. 88. Mnohem přesnější se jeví popis J. Brachtendorfa, Die Struktur, str. 113, podle nějž Augustin postupuje při svém hledání ve dvou krocích, 
případě je však namístě postupovat spíše obezřetně: Augustin sice tvrdí, že když hledá Boha, hledá blažený život, ${ }^{129} \mathrm{z}$ hlediska ,bytí v paměti“ se však od sebe obojí liší: neurčitá představa blaženosti je - na rozdíl od Boha - v paměti od počátku zastoupena. (A je možné uvažovat také o odlišnosti z hlediska cíle hledání: blaženost nakonec není cílem sama o sobě; Augustin to prrinejmenším zpochybňuje, když říká, že tímto cílem je nezištné uctívání Boha pro něj samého. ${ }^{130} \mathrm{~V}$ tomto smyslu je beata vita coby stav toho, kdo již nějak nachází, co hledal, spíše důsledkem nalezení předmětu hledání.) ${ }^{131}$ Přesto Boha zprvu hledáme jako blažený život; jak ale může beata vita coby neurčitá reprezentace v paměti vést $\mathrm{k}$ nalezení něčeho, co není jen ona sama a co v paměti dosud nebylo? ${ }^{132}$

Odpověd' je třeba hledat v analýze memoria jako celku. Interpretace, které čtou Vyznání ve světle Menónovy aporie, se někdy vyznačují menším zájmem o samotnou problematiku paměti. Pak lze dospět k přesvědčení, že Augustin své pátrání v paměti zavrhuje jako cestu, která nevede k cíli. ${ }^{133}$ Sama se spíše domnívám, že jeho postupu v X. knize lépe porozumíme, když $\mathrm{k}$ této analýze přihlédneme, protože výsledek tohoto postupu ji nejen předpokládá, ale je jakousi syntézou dosavadního zkoumání.

přičemž první z nich spočívá v dočasném dosazení blaženého života za původně hledaného Boha, a postupuje tak proto, aby zaměřil pozornost na universalitu usilování o blažený život.

129 Augustin, Confess. X,20,29 / CCL 27,170: Cum enim te, Deum meum, quaero, vitam beatam quaero.

130 Srv. tamt., X,22,32 / CCL 27,172: Est enim gaudium, quod non datur impiis, sed eis, qui te gratis colunt, quorum gaudium tu ipse es.

131 Výslovně je tomu tak např. v týž, De lib. arb. II,13,35 / CCL 29,261.

132 Týž, Confess. X,7,11 / CCL 27,160-161; X,8,12 / CCL 27,161: Transibo ergo et istam naturae meae, gradibus ascendens ad eum, qui fecit me.

133 Srv. S. Menn, The Desire for God, str. 86 a především 89. Mennovo odmítnutí pamětových modelů hledání je však založeno zčásti také na velmi nesamozřejmém čtení pasáže z X. knihy Vyznání (X,20,29 / CCL 27,170), které Menn rozumí nikoli jako rétorické otázce - jak ji chápou všichni mně známí překladatelé -, nýbrž jako pozitivnímu tvrzení, že jsme na blaženost zcela zapomněli. Patrně toto místo čte ve světle Augustinova spisu De Trinitate, XIV,15,21 / CCL 50,449, kde je skutečně o takovémto úplném zapomenutí řeč (srv. níže, pozn. 178). Podobně odmítá „pamět'ové modely“ hledání Boha také S. Macdonald, The Paradox of Inquiry, str. 29-31. Jinak se k této otázce staví např. G. O'Daly, Augustine's Philosophy of Mind, Berkeley - Los Angeles 1987, str. 146-148 a 203, který chápe „bytí v paměti“ jako platné kritérium poznání jak empirických, tak ne-empirických předmětů (srv. Augustin, Confess. X,15,23 / CCL 27,166-167). Podobně J. Brachtendorf, Die Struktur, zejm. str. 43. Podstatné je, že mezikrok zkoumání paměti není možné vynechat. 
Návodné jsou přitom už oba výše popsané modelové příklady hledání v paměti. Pokud jde o analogii s hledáním drachmy, její meze tkví bezesporu $\mathrm{v}$ tom, že předpokládá minulou aktuální přítomnost hledané věci. Proto se jeví pro otázku hledání Boha nevyhovující. Když však Augustin uvažuje o tom, jak máme v paměti blažený život, přinejmenším nevylučuje, že jej známe ve formě vzpomínky na cosi minulého. Podle této hypotézy zjišsění, že blažený život máme nějak v paměti, znamená, že jsme možná blaženými kdysi už byli. Otázka, kdy, kde či jak jsme byli kdysi blaženými - zda každý jednotlivě, nebo všichni v Adamovi tu nicméně zůstává ponechána bez odpovědi. ${ }^{134}$ Pokud by Augustin na tuto hypotézu přistoupil, jeho pozice by byla co do litery věrná Písmu: záleží na tom, jakou váhu přisoudíme theologické koncepci ztotožnění každého jednotlivce s Adamem, která by s sebou v tomto př́ípadě nenesla jen představu sdílení přirozenosti poznamenané pádem (jež bude mít pro Augustina postupně stále větší význam), ${ }^{135}$ ale také myšlenku společné - třebaže implicitní - neporušené zkušenosti, která odkazuje k lidské situaci před pádem. ${ }^{136}$ Jistá obtíž ale tkví v tom, že co do věcných souvislostí je tato pozice spíše nápadně blízká platónské anamnésis (ve smyslu vzpomínky na zkušenost získanou před narozením). Obě tyto koncepce $\mathrm{s}$ sebou totiž nesou problematickou představu pre-existence duše (a v př́ípadě adamovské vzpomínky patrně i těla), na niž Augustin neměl úplně jednoznačný názor a postupem času ji spíše odmítal. ${ }^{137}$ Snad i proto bude hledat jiné východisko.

134 Srv. Augustin, Confess. X,20,29 / CCL 27,171: satago, utrum in memoria sit, quia, si ibi est, iam beati fuimus aliquando, - utrum singilatim omnes, an in illo homine, qui primus peccavit, in quo et omnes mortui sumus et de quo omnes cum miseria nati sumus, non quaero nunc, sed quaero, utrum in memoria sit beata vita. Větší prostor této otázce věnuje Augustin mj. ve spise De civ. Dei, XIV,10 / CCL 48,430: quo modo erant beati in illo memorabili beatitudinis loco, id est paradiso? Srv. tamt.: Amor erat inperturbatus in Deum atque inter se coniugum fida et sincera societate viventium, et ex hoc amore grande gaudium, non desistente quod amabatur ad fruendum.

135 Srv. mimo jiné týž, Confess. VIII,10,22 / CCL 27,127, kde je rozpolcenost vůle vysvětlena Adamovým hříchem. K těmto otázkám srv. L. Karfíková, Milost a vi̊le podle Augustina, Praha 2006.

136 Srv. výše, pozn. 76, o úplném zapomenutí přirovnaném k biblické potopě a též pozn. 133 a 178 o zastřené vzpomínce, resp. zapomenutí na blaženost ve spise O Trojici.

137 Srv. zejm. Augustin, Retract. I,8,2 / CCL 57,22. K této otázce srv. L. Karfíková, Anamnesis. 
Za skutečné předznamenání jeho vlastního řešení proto považuji příklad se ztraceným jménem. Viděli jsme, že memoria si je př́itomna skrze sebe samu, ale že si stejně tak pamatuje na své zapomenutí $(X, 16,25)$, a tudíž se neobsáhne celá; čím více si vzpomíná, tím více má svou lakunární povahu před sebou. Paradigma zapomenutého jména mělo osvětlit tento obtížný život paměti, která si je vědoma, že něčeho pozbyla:

„Snad se to ale nevytratilo úplně, nýbrž ta část, která zůstala, hledala část jinou, protože pamět' cítila, že to, co si přemílala obvykle pospolu (simul), již spolu není, a jako by byla omezena ve svém zažitém chodu, pokulhávajíc žádala, aby jí bylo vráceno, co jí schází?“138

V prvním kroku tedy hledání v paměti předpokládá elementární vědění o zapomenutí (tj. např. vědomí absence čehosi, co bylo v paměti spojeno s tím, co máme nyní před sebou), na hlubší rovině si ale hledané musíme pamatovat i co do jeho obsahu, jinak bychom je nedokázali rozpoznat, jakmile se objeví; to se však ukazuje až v průběhu vzpomínání. Pamět' má tedy více vrstev a motiv částečného pamatování nakonec poukazuje k myšlence jakési původnější soudržnosti pamětové struktury, v níž jsou její jednotlivé části pospolu (simul), třebaže tato soudržnost (alespoň podle Augustinova stanoviska ve Vyznáních) není pro časové bytosti - ve svém celku - nikdy dána.

Pokud jde o tuto simultaneitu latentních obsahů paměti, př́mo se nabízí uvažovat o tom, že by Augustin mohl od př́íkladu hledání jména postoupit dále a rozvinout zde to, co již vyložil v souvislosti s věcmi samými. Myšlenka, že právě res ipsae tvoří jakousi vnitřně soudržnou inteligibilní sféru, mu patrně není nijak cizí. Augustin ale ve Vyznáních nevolí tuto povýtce intelektuální cestu, kterou známe z jeho raných spisů. ${ }^{139}$ Důvodů pro to má patrně víc; jeden z nich je snad ten, že jej v jeho duchovní autobiografii více zajímá samotné vnitřní tíhnutí k hledání, které je někdy obtížně postižitelné, ale které je podle něj vlastní každé

138 Srv. Augustin, Confess. X,19,28 / CCL 27,170: An non totum exciderat, sed ex parte, quae tenebatur, pars alia quaerebatur, quia sentiebat se memoria non simul volvere, quod simul solebat, et quasi detruncata consuetudine claudicans reddi quod deerat flagitabat? K užití slovesa volvere, resp. revolvere v souvislosti s pamětí srv. týž, De mag. 1,2 / CCL 29,159: sic quoque locutione nihil aliud agere quam commemorare, cum memoria, cui verba inhaerent, ea revolvendo facit venire in mentem res ipsas, quarum signa sunt verba.

139 Srv. např. II. knihu Augustinova dialogu $O$ svobodném rozhodování nebo O hudbě, VI. 
bytosti. Snad právě přemýšlení o povaze touhy obrací jeho pozornost k otázce blaženého života. Pamět' tohoto života má sice některé společné rysy s res ipsae, nebot' jeho tajuplné poznání (notitia $)^{140}$ - stejně jako číselné zákonitosti $(X, 12,19)$ - není řecké nebo latinské, nýbrž je to jedna a táž věc sama uložená v paměti $(X, 20,29)$. Přesto se ale podle Augustina od poznání res ipsae liší právě tím, že po blaženosti všichni bez výjimky a bez ustání toužíme:

„Snad si pamatujeme [blaženost] tak jako čísla? Ne, protože ten, kdo má jejich znalost (notitia), už neusiluje o to jich dosáhnout, když však máme znalost blaženého života, a proto jej milujeme, chceme jej přece dosáhnout, abychom byli blažení." ${ }^{141}$

Pro obeznámenost s blažeností je tedy příznačné, že s sebou nese touhu ve smyslu úsilí o dosažení určitého stavu bytí. Uvedený rozdíl lze ilustrovat i lexikálně: když před Augustinem vyvstane, po čem předtím ve své paměti marně pátral, řekne si: „to je ono“ - hoc est. A když po určitém úsilí najde ve své paměti zákonitost ve smyslu res ipsae, konstatuje: „tak tomu je, to je pravda“ - ita est, verum est. Naproti tomu o blaženém životě praví, že jej hledá, dokud neřekne: „stačí, [už] je zde“ - sat, est illic. ${ }^{142}$

Viděli jsme, jak Augustin v souvislosti s věcmi samými vylíčil proměnlivost paměti, která ponechána sama sobě tíhne k des-integraci, jejíž protiváhou je práce myšlení ve smyslu „shánění dohromady“ (jak etymologizuje výraz cogitare). V analýze blaženého života naproti tomu načrtává myšlenku, podle níž mysl či pamět' naopak tíhne k sebe-integraci, jestliže při svém hledání dokáže sledovat nejvlastnější zacílení touhy, která je konstitutivně touhou po Bohu. (V tomto ohledu je možné ve Vyznáních rozeznat jakýsi předobraz myšlenky bohatě rozvinuté ve

140 Srv. týž, Confess. X,20,29 / CCL 27,171: Nescio quomodo noverunt eam ideoque habent eam in nescio qua notitia...

141 Srv. tamt., X,21,30 / CCL 27,171: Numquid sicut meminimus numeros? Non; hos enim qui habet in notitia, non adhuc quaerit adipisci, vitam vero beatam habemus in notitia ideoque amamus et tamen adhuc adipisci eam volumus, ut beati simus. Už v raných Hovorech k sobě (Solil. I,5,11 / CSEL 89,18) zmiňuje Augustin rozdíl mezi radostí, kterou má z poznávání geometrických předmětů, a tou, kterou by měl z poznání Boha.

142 Srv. týž, Confess. X,19,28 / CCL 27,170, resp. X,10,17 / CCL 27,164, a také X,20,29 / CCL 27,170 (Quomodo ergo quaero vitam beatam? Quia non est mihi, donec dicam: „Sat, est illic.“); Solil. I,2,7 / CSEL 89,11. 
spise $O$ Trojici.) Současně se ale v X. knize poprvé jasně říká, že touha je v prvním kroku vždy vztahem $\mathrm{k}$ něčemu už známému: blaženost bychom totiž nemilovali, kdybychom ji neznali (neque enim amaremus eam, nisi nossemus) ${ }^{143}$ A Bůh zpočátku poznaný není. Ukazuje se tedy, že aporetická povaha je vlastní samotné touze. Jak už bylo řečeno, Augustin ve věci universální touhy po blaženém životě přejímá klasické antické topos dovolávaje se Ciceronova Hortensia. ${ }^{144}$ Vyznání představují jeden ze zajímavých pokusů, jak tento ,axióm“ podrobněji zkoumat, a tak zároveň filosoficky rozvinout onu formuli o povaze touhy ze samého počátku spisu. ${ }^{145}$

\subsection{Vzpomínka na radost}

Augustin tedy zprvu hledá obecně sdílený předmět touhy, a nikoli cíl vymezený na základě filosofické reflexe. Přirozeně se nabízí ztotožnit blaženost s ,dobrým životem“, pokud o něm nebudeme uvažovat jen jako o jednotlivém životě, na který v jeho celkovosti pohlížíme zvnějšku, ale zároveň jako o životě, který je vnitřně prožívaný jako dobrý. I to je ale pro Augustina, jak se zdá, př́iliš sofistikované přiblížení. Proto když se ptá, jakým způsobem máme blažený život v paměti, odpovídá si docela prostě, že snad (fortasse) jako radost. K této prvotní identifikaci bude mít i hlubší důvody - jak ještě uvidíme. Zprvu ale naráží na cosi elementárního: po blaženosti toužíme jako po radosti. Touha se však přednostně vztahuje $\mathrm{k}$ předmětu, který je nepřítomný. Zároveň platí, že tento předmět musíme znát, a proto toužíme po radosti, kterou jsme již kdysi zakusili. Ovšem radost - tak, jak si ji nyní vyvoláváme z paměti nemá stejnou afektivní kvalitu, jakou měla v minulosti. Zde se Augustin vrací ke svému výkladu přítomnosti duševních stavů či hnutí (affectiones animi) v paměti. ${ }^{146}$ Připomeňme si jejich hlavní rysy.

Afekce máme uloženy ,jiným, velmi odlišným [způsobem], jakým má sebe samu síla paměti““. ${ }^{147}$ Tento specifický sebevztah paměti tkví v distanci, která nevylučuje koexistenci protikladných stavů: „Č́ím to je, že když si v radostném rozpoložení vzpomínám na svůj minulý smutek, duch má radost a pamět' smutek - duch se raduje z toho, že je v něm

143 Týž, Confess. X,20,29 / CCL 27,171.

144 Srv. výše, pozn. 40.

145 Srv. týž, Confess. I,1,1 / CCL 27,1 (viz také výše, pozn. 56).

146 Srv. celek výkladu: tamt., X,14,21-19,28 / CCL 27,165-170.

147 Srv. tamt., X,14,21 / CCL 27,165: sed alio [modo] multum diverso, sicut sese habet vis memoriae. 
radost, zatímco pamět' není nijak smutná z toho, že je v ní smutek?“148 $\mathrm{V}$ případě affectiones ze sebe duch-pamět' uchopuje s odstupem času jen jakýsi derivát původního kvalitativního stavu. Přesto si je Augustin jist, že hnutí ducha jsou v paměti př́tomna, protože o nich můžeme mluvit a rozlišovat je. To by nebylo možné, kdyby se zde kromě zvuků jmen nenacházely také pojmy těchto věcí samotných (rerum ipsarum notiones). ${ }^{149}$ Pamět' se tedy k afekcím při jejich opětovném zpřítomnění vztahuje jako k pojmům (notiones), jež chápe, aniž by jimi byla nutně pohnuta.

V úvaze o paměti blaženého života se Augustin k těmto motivům vrací: pamět' ví, co je blažený život, i když si vedeme bídně. Radost je navíc netělesná: „Svou radost jsem tělesným smyslem nikdy neviděl ani neslyšel..., ale zakusil jsem ji ve svém duchu, když jsem byl veselý, a její poznání (notitia) ulpělo v mé paměti. “150 Toto poznání se tedy nezakládá na významu odvozeném z užívání slov ani na pozorování druhých, nýbrž na vnitřní zkušenosti (notitia interior). ${ }^{151}$

Na jedné straně je tedy radost prvním orientačním bodem touhy po blaženém životě, a jeví se tak - v jistém smyslu - jako protiváha myšlenky touhy, která přirozeně směřuje $\mathrm{k}$ Bohu jako svému jedinému a poslednímu předmětu, v němž může najít spočinutí: nebot' nakolik se touha smí řídit také radostí, nepřináší hledání jen permanentní frustraci pramenící z nedosažitelnosti cíle. Na straně druhé však postupně vychází najevo, že dílčí cíle, v nichž různí lidé radost hledají a někdy i nacházejí, jsou velmi rozmanité. Všichni - ačkoli volí různá životní povolání (kupř. jeden se chce stát vojákem, a druhý nikoli) ${ }^{152}$ - se totiž podle Augustina shodují v tom, že chtějí být blažení, nebot' se chtějí radovat a „tuto radost nazývají blaženým životem“. ${ }^{153}$ Toto obecné mínění však zůstává

148 Srv. tamt., X,14,21 / CCL 27,166: Quid est hoc, quod cum tristitiam meam praeteritam laetus memini, animus habet laetitiam et memoria tristitiam laetusque est animus ex eo, quod inest ei laetitia, memoria vero ex eo, quod inest ei tristitia, tristis non est? Num forte non pertinet ad animum?

149 Srv. tamt., X,14,22 / CCL 27,166. O něco dále ve shrnutí (tamt., X,17,26 / CCL 27,168) užívá Augustin termíny notio a notatio souznačně.

150 Srv. tamt., X,21,30 / CCL 27,171: neque umquam corporis sensu gaudium meum vel vidi vel audivi vel odoratus sum vel gustavi vel tetigi, sed expertus sum in animo meo, quando laetatus sum, et adhaesit eius notitia memoriae meae...

151 Srv. tamt., X,21,30 / CCL 27,171.

152 Srv. tamt., X,21,31 / CCL 27,172.

153 Srv. tamt.: Ita se omnes beatos esse velle consonant, quemadmodum consonarent, si hoc interrogarentur, se velle gaudere atque ipsum gaudium vitam beatam vocant. 
jen u „obrazu radosti““ (imago gaudii), k němuž se vůle upíná154 a který nacházíme v paměti. ${ }^{155}$ Co má Augustin přesněji na mysli, když hovoří o ,jakémsi obrazu“, není zcela jasné. Může mít na mysli bud’ radost zaměřenou $\mathrm{k}$ tělesným věcem (nebot' jakožto obrazy máme podle něj v paměti př́tomny minulé tělesné věci či stavy), ${ }^{156}$ nebo má na mysli obraz ve smyslu pouhého odlesku pravé radosti (gaudium verum). ${ }^{157}$ Tento problém jej každopádně přivádí k otázce, co blažený život doopravdy je (sed quid est hoc?). A hned nato i k odpovědi: není to nic jiného než radost z Boha: „To je i sám blažený život: radovat se u tebe, z tebe a kvůli tobě." $" 158$

Jestliže se však všichni - jak vidno - nechtějí radovat právě z Boha, znamená to, že je třeba přehodnotit základní východisko, podle nějž všichni touží po blaženém životě? Vždyt' i ty bytosti, které objevily, že hledajíce blaženost hledají vlastně Boha, ve svém úsilí mnohdy ochabují a zůstávají připoutány $\mathrm{k}$ nižším dobrům.

Nikoli, tato teze stále platí. Radost může být docela dobře vodítkem hledání, jestliže si o ní - přesněji o jejím předmětu - dokážeme dodatečně zformulovat „správné mínění“. A zdá se, že kořen obtíží tkví nakonec v akrasii, nebot' lidé podle Augustina ,upadají do toho, na co stačí, a jsou s tím spokojeni, protože to, nač nestačí, nechtějí do té míry, aby na to stačili““. ${ }^{159}$ Zároveň ale podle něj existuje přímá úměra mezi vytrvalostí vůle a dostatečně jistým poznáním. ${ }^{160}$

154 Srv. tamt., X,22,32 / CCL 27,172: Ab aliqua tamen imagine gaudii voluntas eorum non avertitur.

155 Srv. tamt., X,21,31 / CCL 27,172: Quae quoniam res est, quam se expertum non esse nemo potest dicere, propterea reperta in memoria recognoscitur, quando beatae vitae nomen auditur.

156 Srv. tamt., X,8,12-15 / CCL 27,161-163.

157 Srv. tamt., X,22,32 / CCL 27,172.

158 Srv. tamt.: Et ipsa est beata vita, gaudere ad te, de te, propter te: ipsa est et non est altera.

159 Srv. tamt., X,23,33 / CCL 27,172-173: An omnes hoc volunt, sed quoniam caro concupiscit adversus spiritum et spiritus adversus carnem, ut non faciant quod volunt, cadunt in id quod valent eoque contenti sunt, quia illud, quod non valent, non tantum volunt, quantum sat est, ut valeant?

160 Srv. tamt., X,21,31 / CCL 27,172: Quod nisi certa notitia nossemus, non tam certa voluntate vellemus. 


\subsection{Poznání pravdy uložené v paměti}

Reflexe „správných“ či neklamných radostí Augustina přivádí k popisu intencionálního vztahu k pravdě, který je podobně jako touha po radosti zakotven v paměti. Lidé by podle něj nemilovali blažený život - charakterizovaný nyní jako radost z pravdy (gaudium de veritate) -, kdyby neměli v paměti alespoň „nějaké poznání (aliqua notitia) pravdy““. ${ }^{161}$

Tvrzení, že pravda je předmětem lásky, Augustin vyvozuje z pozorování, že nechceme být klamáni, ani když sami klameme. Po pravdě ale „netoužíme“ stejně bezprostředně jako po radosti. Důvodem je patrně zpo̊sob jejího ukazování, nebot' pravda odhaluje ve svém světle nejen poznávané předměty, ale také poznávajícího: pravda je milována, a proto také chceme, aby to, co milujeme - i když je to něco jiného než pravda -, byla pravda. Odtud však může pocházet odpor k pravdě: jednak z lásky k této jiné věci, jíž pravda protiřečí, jednak z neochoty přiznat si vlastní pomýlenost. ${ }^{162}$ Pro „radost z pravdy“ tedy musí být poznávající disponován: nestačí, aby se z ní radoval, když se mu dává poznat (když „záříi“), ale aby to dovedl, i když mu nastavuje zrcadlo. Jinak se v něm nemůže trvale usídlit, protože Pravda podle Augustina nesnese, aby se o tutéž duši dělila se lží (ve smyslu sebeklamu). ${ }^{163}$

Otevírá se tu však ještě zásadnější motiv, než je problém „způsobilosti“ subjektu poznání, a tím je theologické, resp. christologické pojetí Pravdy. Už v prvním výměru blaženého života je řečeno, že radost z pravdy je radostí z Boha. ${ }^{164}$ Extenzivněji se toto téma objevuje v závěru X. knihy $(X, 40,65-41,66) .{ }^{165}$ Když se Augustin na konci svého zkoumání paměti $(X, 24,35-26,37)$ vrací k otázce, kde Boha nalezl, dospívá $\mathrm{k}$ tomu, že jej našel všude tam, kde našel pravdu, totiž Pravdu samu

161 Srv. tamt., X,23,33 / CCL 27,173: Amant enim et ipsam, quia falli nolunt, et cum amant beatam vitam, quod non est aliud quam de veritate gaudium, utique amant etiam veritatem nec amarent, nisi esset aliqua notitia eius in memoria eorum.

162 Srv. tamt., X,23,34 / CCL 27,173. Na tomto místě jde navíc zřejmě o narážku na $J 8,40$ a na pašijový př́iběh.

163 Srv. tamt., X,41,66 / CCL 27,191: Itaque amisi te, quia non dignaris cum mendacio possideri. $\mathrm{K}$ tomuto ontologickému rozměru, pokud jde o poznávajícího, snad také odkazují kapitoly následující po analýze paměti v celé druhé části X. knihy (X,28,39-41,66 / CCL 27,175-191).

164 Srv. tamt., X,23,33 / CCL 27,173: hoc est enim gaudium de te, qui veritas es, Deus, inluminatio mea.

165 Srv. tamt., X,40,65 / CCL 27,190: Ubi non mecum ambulasti, veritas, docens, quid caveam et quid appetam... Srv. tamt., X,41,66 / CCL 27,191: Tu es veritas super omnia praesidens. 
(ipsam veritatem; X,24,35). A tímto směrem ukazuje i výsledek úvahy o blaženém životě: ,[Lidský duch] bude tedy blažený, jestliže se bude radovat - žádnými těžkostmi nerušen - jen ze samotné Pravdy, jî̌ jsou pravdivé všechny věci.“" ${ }^{166}$

Přechod od dílčích pravd, které nacházíme v paměti, k Pravdě jako zdroji pravdivosti všech věcí je přitom sám o sobě nesamozřejmý a v X. knize (ani jinde ve Vyznáních) není podrobněji vysvětlen. Zároveň jde o krok, který nebyl ani pro Augustina - soudě z jeho vyprávění - nijak snadný. K jeho přiblížení často užívá (novo)platónskou a biblickou metaforiku světla: ${ }^{167}$ když líčí své studium knih svobodných umění, praví, že se z nich radoval ( gaudebam in eis), ačkoli nevěděl, odkud pochází to, co je v nich pravdivé a jisté (verum et certum). „Byl jsem tedy obrácen zády ke světlu a tváří k věcem, které jím byly osvětleny, a proto zůstávala moje tváŕ, jíž jsem osvětlené věci rozlišoval, sama neosvětlena." "168 Podobný problém později viděl i u pohanských učenců, kteří podle něj „,ŕíkají mnoho pravdivých věcí o tvorech, a přesto nenacházejí Pravdu, která tvory učinila“. ${ }^{169}$ Jedno z mála míst, v němž je - i když spíše nepřímo - řeč o nalezení Pravdy jako samotného zdroje bytí, bezprostř̌edně předchází poznání Boha, jak je vylíčeno v VII. knize: ,a viděl jsem, že [věci] ti vděčí za své bytí (et vidi tibi debere quia sunt)..., že všechny věci jsou pravdivé, nakolik jsou, a že nepravda není nic jiného než domněnka, že je něco, co není.“"170

166 Srv. tamt., X,23,34 / CCL 27,174: Beatus ergo erit, si nulla interpellante molesta de ipsa, per quam vera sunt omnia, sola veritate gaudebit.

167 Srv. např. tamt., X,40,65 / CCL 27,190-191: quia lux es tu permanens, quam de omnibus consulebam, an essent, quid essent, quanti pendenda essent: et audiebam docentem ac iubentem (,nebot' ty jsi Světlo, které trvá a kterého jsem se tázal na radu o tom všem: zda to je, co to je a jakou to má váhu; a poslouchal jsem, jak mě učíš a co mi přikazuješ").

168 Srv. tamt., IV,16,30 / CCL 27,55: Et gaudebam in eis et nesciebam, unde esset quidquid ibi verum et certum esset. Dorsum enim habebam ad lumen et ad ea, quae illuminantur, faciem; unde ipsa facies mea, qua illuminata cernebam, non illuminabatur. Srv. Platón, Resp. 507a-509b a Plótinos, Enn. V,5,7; II,3,6.

169 Srv. Augustin, Confess. V,5,5 / CCL 27,59: Et multa vera de creatura dicunt et veritatem, creaturae artificem, non pie quaerunt et ideo non inveniunt...

170 Tamt., VII,15,21 / CCL 27,106. V celém znění: Et respexi alia et vidi tibi debere quia sunt et in te cuncta finita, sed aliter, non quasi in loco, sed quia tu es omnitenens manu veritate, et omnia vera sunt, in quantum sunt, nec quidquam est falsitas, nisi cum putatur esse quod non est. 
Tento metafysický krok ztotožnění Boha se zdrojem bytí a pravdy ze VII. knihy ${ }^{171}$ spolu s jeho (roz)poznáním jako duchovní substance, jak bylo popsáno výše,${ }^{172}$ koresponduje s tezí o konstitutivní povaze touhy, která nemůže setrvat jen u stvoření (touha, nakolik je mj. touhou po pravdě, nakonec nemůže dojít naplnění jinde než v Pravdě, z níž mnohost pravd pochází). Zároveň ale musí být tato filosoficko-theologická koncepce podle Augustinova přesvědčení doplněna christologickým chápáním Pravdy, které nepřináší přechodnou „,vizi“ inteligibilní skutečnosti v (novo)platónském smyslu, ale ukazuje „,cestu“ k blažené vlasti. ${ }^{173}$ Domnívám se, že momentu přechodu od dílčích pravd uložených v paměti k nalezení Pravdy jako zdroje veškeré pravdivosti (a bytí), odpovídá v X. knize Augustinův závěr o tom, že Boha vposledku nenalezl v paměti, tj. v sobě, nýbrž nad sebou: „,kde jsem tě tedy našel, abych tě poznal, když ne v tobě nad sebou?" (ubi ergo te inveni, ut discerem te, nisi in te supra me? $)^{174}$ Zároveň se však zdá, že schopnost poznávat pravdivé věci, jak se nacházejí v paměti, pro Augustina zůstává předpokladem tohoto rozpoznání.

\subsection{Gaudium de veritate}

Z těchto analýz pojmu pravdy lze dospět k závěru, že by si Augustin při hledání blaženého života mohl vystačit jen s ní. Přesto ve všech formulacích zdůrazňuje konstitutivní roli radosti. ${ }^{175}$ Přítomnost tohoto hnutí duše pro něj dokonce není v rozporu s nezištnou povahou (gratis) vztahu k Bohu: ,existuje totiž radost, která ... [je dána] jen těm, kdo tě nezištně ctí (qui te gratis colunt) a jejichž radostí jsi ty sám““. ${ }^{176}$ Snad je tomu tak proto, že radost - podobně jako blažený život - je pro Augustina nakonec spíše důsledkem nalézání pravdy (resp. Pravdy) než jeho motivem (tím je patrně jen zpočátku, dokud zůstává nereflektovaná). Úzce to souvisí

171 Tomuto aspektu Augustinova myšlení se věnuje mj. W. Beierwaltes, Regio beatitudinis. Zásadní je toto metafysické ztotožnění také pro S. Menna, který jej analyzuje ve své knize Descartes and Augustine, Cambridge 1998, zejm. str. 73-206; v roce 2014 navázal na tyto své analýzy článkem The Desire for God.

172 Srv. podkapitola Poznání Boha.

173 Srv. výše, pozn. 101 a též Augustin, Confess. V,5,5 / CCL 27,59: Non noverunt hanc viam, qua descendant ad illum a se et per eum ascendant ad eum. Nepoznali totiž Krista jakožto ,cestu, po které mají sestupujíce ze sebe k němu vystoupit skrze něj k němu“. (Srv. S. Menn, Descartes and Augustine, str. 132.)

174 Augustin, Confess. X,26,37 / CCL 27,175.

175 Srv. k tomu např. W. Beierwaltes, Regio beatitudinis, str. 45.

176 Srv. Augustin, Confess. X,22,32 / CCL 27,172. Srv. výše pozn. 130. 
s katharsis toho, kdo poznává: jestliže nezbývá než poznávat pravdu i tehdy, když není pro poznávajícího příznivá, pak je schopnost radovat se z ní nepřímo úměrná sklonu k sebeklamu. A jak jsme viděli, klam utkaný z pouhých obrazů radosti - je spojený s rozptýleností v časných věcech: lidé se nedokáží z pravdy radovat, ,protože jsou víc zaměstnáni jinými věcmi, a ty je spíš činí nešt’astnými“. ${ }^{177}$

Jestliže se tedy z Augustinovy počáteční analýzy blaženého života jako gaudium de veritate zdálo, že máme v paměti dva samostatně zastoupené typy obsahů, totiž radosti z různých věcí (jako první orientační bod touhy) a pravdivé poznatky (jako její dodatečný korektiv), pak jeho další úvahy ukazují, že pro správné porozumění blaženosti je rozhodující pochopit, jak jsou spolu tyto dva typy obsahů spojeny. Pohlédneme-li totiž do své paměti, skutečně tu najdeme zkušenost radosti, která není vždy radostí z pravdy, a také poznání pravdy, z nějž se nijak neradujeme. Když má Augustin vysvětlit tuto nespojitost z epistemologického hlediska, a tím si připravit odpověd’ na otázku, proč lidé nedostávají své nejvlastnější touze, říká, že si namnoze vzpomínají na blažený život nezřetelně (tenuiter meminerunt). ${ }^{178}$ Jak tedy přesněji rozumět tomuto ideálnímu spojení (totiž gaudium de veritate), které je jádrem výkladu o implicitním poznání Boha ve Vyznáních?

Tuto otázku si kladlo více interpretů. Podle některých (1) se Bůh lidem dává poznat $\mathrm{v}$ obou těchto podobách - radosti a pravdy; přesněji řečeno, když hovoříme o pojmu Boha, nevysloveně do něj zahrnujeme i radost a pravdu, a když máme na mysli pojmy radosti a pravdy, zahrnujeme do nich také Boha. ${ }^{179}$ Jiní autoři (2) chápou radost a prav-

177 Srv. tamt., X,23,33 / CCL 27,173: Cur non beati sunt? Quia fortius occupantur in aliis, quae potius eos faciunt miseros quam illud beatos, quod tenuiter meminurunt. Srv. též Augustinovy zmínky o hříšnosti obracení k nižšímu např. tamt., I,20,31 / CCL 27,17: Hoc enim peccabam, quod non in ipso, sed in creaturis eius me atque ceteris voluptates, sublimitates, veritates quaerebam, atque ita inruebam in dolores, confusiones, errores.

178 Srv. Augustin, Confess. X,23,33 / CCL 27,173 (viz pozn. 177). Ještě v X. knize spisu $O$ Trojici, dokončené patrně výrazně dříve než knihy XIII-XV, bychom našli pasáž, v níž Augustin podotýká, že si na blaženost uchováváme jakousi tajuplnou či zastřenou vzpomínku (occulta memoria). Srv. týž, De Trin. X,3,5 / CCL 50,317-318. V knize XIV však už bez zaváhání říká, že i pokud by duše znala Boha v Adamovi nebo jinde před životem v tomto těle (tj. př̀i stvoření duše a před jejím „vsazením“ do těla), všechno v ní bylo zcela smazáno zapomněním. Srv. tamt., XIV,15,21 / CCL 50,450: quidquid horum est oblivione deletum est.

179 Srv. J. Brachtendorf, Die Struktur, str. 114: „,Glück‘ und ,Wahrheit‘ werden mitverstanden, wenn von Gott die Rede ist....". 
du jako dva ,tokeny“, jež nakonec v jakémsi souběhu vedou k nalezení Boha jako „pravé radosti“, tj. opravdového a původního zdroje radosti. ${ }^{180}$ Poukaz k těmto universálně sdíleným empirickým danostem má být alternativou metafysického řešení paradoxu hledání, které počítá s myšlenkou anamnésis. ${ }^{181}$ A konečně podle třetí intepretace (3) Augustin nechce ani tak říci, že bychom toužili po „pravé radosti“, nýbrž po radosti, která se zakládá na pravdách, k nimž postupně dospíváme. Nebot' radost má určitý propoziční obsah (radosti si pro sebe obvykle nějak vykládáme, jsou součástí př́iběhu) a pravdou ve spojení gaudium de veritate se míní předmět této radosti. Hledání se tedy nechává vést reflexí této základní intencionality namíŕené k pravdě. A - jak jsme viděli - Augustin nakonec (už v VII. knize a později i v knize X.) pravdu a Boha ztotožňuje. ${ }^{182}$

\subsubsection{Dva pohledy na povahu touhy}

Domnívám se, že Augustinova analýza nabízí dvě - vzájemně úzce spjatá - hlediska, jak spojení gaudium de veritate chápat. $\mathrm{Z}$ jedné perspektivy ${ }^{183}$ se implicitní forma intencionálního vztahu k Bohu - v souladu s poslední uvedenou interpretací (3) - zakládá na přirozenosti touhy, která vědomě či bezděčně k Bohu směřuje, a její explikace se odvíjí více či méně kontinuálně: předmětem touhy je zprvu radost a dodatečná reflexe této radosti ukazuje její sepětí s otázkou pravdivosti. Tak jako si duch pamatuje spolu s pravdivými poznatky i omyly, takže na jedny navazuje, zatímco od druhých upouští, tak se také při vzpomínání ukazují být hodné touhy jen některé radosti, zatímco jiné jsou dodatečně shledány zavrženíhodnými - v závislosti na jejich předmětu. ${ }^{184}$ Zatímco se totiž podle Augustina ve stavu rozradostnění můžeme snadno těšit i z klamu, zpětně podle něj nedokážeme toužit po radosti, která se ukázala být klamná. Nejde tedy jen o samotnou proměnu kvality affectiones, ale

180 Srv. S. Macdonald, The Paradox of Inquiry, zejm. str. 34-37.

181 Srv. tamt., str. 20.

182 Srv. S. Menn, The Desire for God, zejm. shrnutí na str. 90-91. Srv. k tomu především jeho knihu Descartes and Augustin.

183 Tato perspektiva by patrně zhruba odpovídala Mennovu výkladu (srv. The Desire for God).

184 Augustin, Confess. X,21,30 / CCL 27,172: Nam et de turpibus gaudio quodam perfusus sum, quod nunc recordans detestor atque exsecror, aliquando de bonis et honestis, quod desiderans recolo, tametsi forte non adsunt, et ideo tristis gaudium pristinum recolo. 
také o posun v tom, z čeho se v průběhu času radujeme. ${ }^{185}$ Tímto způsobem je pak možné se postupně přibližovat $\mathrm{k}$ cíli. Patrně tedy existují správné (či pravdivé) radosti, které ještě nejsou radostmi z Boha, např. radosti ze ctností, a které jsou předpokladem jeho poznání. Zkoumáme-li dále pravdu, nahlížíme na ni jako na měřítko či normu pravdivosti všech věcí (jak už o tom byla řeč). Pokud bychom si tedy kladli otázku, co je zde - namísto anamnésis - kritériem hledání, odpověd’ by musela znít, že toto kritérium je zpočátku pouze negativní (odmítání těch radostí, které brání vyvstání jiných, pravdivějších, lepších apod.). Kdybychom ale chtěli problém kritéria podrobit oné kruciální otázce „proč ne raději nepravdu?"“, ${ }^{186}$ museli bychom poukázat k metafyzicky zakotvené představě o přirozenosti touhy, která je nakonec intencionálním vztahem k pravdě.

Celou věc však lze vidět i z opačné perspektivy: Augustin vychází z toho, že v paměti máme uloženu radost $\mathrm{z}$ různých věcí a pravdivé poznatky jako dva nezávislé typy obsahů. $Z$ jeho líčení se někdy zdá, jako by prožitek radosti a poznávání pravdy vytvářely dvě paralelní linie zkušenosti, které se jen zřídka setkávají. Když navíc uvažuje o tom, co brání nalézt blažený život, cituje Pavlův list Galatským, ${ }^{187}$ jenž vyslovuje tezi o dvojí touze či lásce (duchovní a tělesné), která bude mít pro Augustina velký význam (a hrála také zásadní roli v líčení jeho konverze v knize osmé). ${ }^{188}$ Toto hledisko rezonuje ještě v druhé polovině X. knihy věnované pokušením, kde Augustin hořce konstatuje: „Radosti, nad kterými by se mělo plakat, ve mně bojují se smutky, z kterých bych se měl radovat - a nevím, na kterou stranu se přikloní vítězství... " ${ }^{189}$ Přestože tedy mnohdy ví, co by mělo být předmětem smutku a co radosti, je mu zatěžko svému poznání dostát. Podobné pasáže přinejmenším komplikují výše načrtnutou optimistickou metafysiku či antropologii touhy. Pokud bychom tedy celý problém viděli z hlediska této rozpolcenosti touhy

185 Srv. S. Menn, The Desire for God, str. 90-91, který se v tomto bodě vymezuje vůči tomu, jak chápe radost, resp. spojení gaudium de veritate, $\mathrm{S}$. Macdonald.

186 Srv. F. Nietzsche, Mimo dobro a zlo, přel. V. Koubová, Praha 1996, str. 9: „Dejme tomu, že chceme pravdu: proč ne raději nepravdu?“

187 Srv. Augustin, Confess. X,23,33 / CCL 27,172-173; Ga 5,17 (caro concupiscit adversus spiritum et spiritus adversus carnem).

188 Srv. Augustin, Confess. VIII,10,22 / CCL 27,127 (srv. výše, pozn. 135).

189 Tamt., X,28,39 / CCL 27,175: Contendunt laetitiae meae flendae cum laetandis maeroribus, et ex qua parte stet victoria nescio. Contendunt maerores mei mali cum gaudiis bonis, et ex qua parte stet victoria nescio. 
a frapantní nespojitosti mezi affectio radosti a poznáváním pravdy, co by v takové situaci mohlo být kritériem hledání?

\subsubsection{Spojité obsahy paměti}

Mám za to, že Augustin zvažuje - jako doplněk a protiváhu této méně optimistické perspektivy - také jiné pozitivní kritérium, které by mělo vysvětlit, proč se radost vůbec může spojovat s pravdou. Tímto komplementem touhy má být sama hlubší struktura paměti. Autor Vyznání o tomto doplnění uvažuje ve dvou variantách: první z nich je už zmiňovaná adamovská vzpomínka, která má odkazovat k archetypu života v radostné kontemplaci pravdy (této první možnosti se ale Augustin podrobněji nevěnuje). Druhou je výše načrtnutá představa určitého okruhu simultánních obsahů - v jiných textech říká také „vtisků“ - paměti. Mezi ně by patřily jakési Boží charakteristiky nebo rysy Božího působení, které jsou zároveň universální. V Augustinově díle bychom vedle pojmů radosti a pravdy mohli v tomto smyslu uvažovat také o pojmu moudrosti ( $O$ svobodném rozhodování, II) či dobra, spravedlnosti nebo věčnosti (O Trojici) ${ }^{190}$ Vyznání jsou ovšem specifická právě promýšlením pojmu radosti, který má povahu afektu a k němuž se zprvu vztahujeme jako k minulé zkušenosti (navíc jde - jestliže vyloučíme adamovskou vzpomínku - o pouhou empirickou minulost); jako by záleželo na př́běhu každé jednotlivé bytosti, čím pojem radosti naplní. Augustinovo „rozpomínání " tedy vychází z touhy inspirované minulou radostí, ale jen proto, aby se chybění něčeho, co tu bylo, ukázalo být chyběním čehosi, co tu vždy již je. Jestliže však uskutečnění tohoto kroku (nebo spíše série kroků) od minulého ke stále přítomnému předpokládá určitou metafysickou koncepci simultaneity obsahů paměti, bezpochyby nejde o simultánní spojení veškerých předmětů poznání

190 V II. knize spisu O svobodném rozhodování se říká, že jsou naší mysli vtištěny pojmy blaženosti a moudrosti, díky nimž s jistotou víme, že chceme být blažení a moudří. Srv. týž, De lib. arb. II,9,26 / CCL 29,254. Ve spise O Trojici (De Trin. XIV,15,21 / CCL 50,450-451) Augustin cituje starozákonní pasáže, v nichž je řeč o duši, jež si rozpomíná (reminiscitur) na Hospodina $(D t 8,14)$ nebo se upamatovává (commemoratur), aby se k němu obrátila (Ž 21[22],28). Opět přitom vychází z jakýchsi universálních pojmů (věčnosti či spravedlnosti) vtištěných Bohem do paměti (přesněji „do srdce“) jako pečetním prstenem do vosku. Otázku rozpoznání Boha jako původce těchto „vtisků“ (přesněji „knihy světla, které se říká Pravda“) a obrácení k němu tedy i zde spojuje s určitou dispozicí a zároveň aktivitou paměti. O vtištěných pojmech spravedlnosti je v tomto smyslu řeč už v knize VIII (srv. tamt. VIII,3,4 / CCL 50,272 a VIII,6,9 / CCL 50,280-284). K výkladu pasáže ze XIV. knihy spisu O Trojici (XIV,15,21) srv. L. Karfíková, Anamnesis, str. 76-78. 
(po vzoru novoplatónského Intelektu), ale o pouze částečnou spřízněnost specifických pamět'ových obsahů či vtištěných pojmů; v daném kontextu notio radosti a notitia pravdy. ${ }^{191}$

Náčrt myšlenky simultánní dimenze paměti Augustin předestřel v souvislosti s výkladem částečného zapomenutí. I v př́ípadě gaudium de veritate jedna část paměti - již jsme si právě zpřítomnili, tj. zkušenost či pojem minulé radosti - jakoby „pokulhává“ a hledá jinou část, a tím na sebe uplatňuje měřítko přítomné pravdy, nebot' v hlubších vrstvách memoria do sebe oba tyto obsahy zapadají, a proto žádají doplnění „části“, která jim schází. Pokud bychom tuto spojitost nepředpokládali, nebylo by jasné, proč neulpívat na všech radostech (bez ohledu na rozlišení klamu a pravdivosti). Tomuto Augustinovu myšlenkovému postupu by snad odpovídala první uvedená interpretace (1), podle níž je radost a pravda zahrnuta v pojmu Boha. Pro Vyznání je ale charakteristická právě aporetická - a současně autobiografická - forma hledání, v níž k poznání Boha nestačí tak docela racionální analýza jeho pojmu. Spíše se zdá, že zvláštní význam, který tu získává vzpomínka na minulou radost a tím i empirická zkušenost, je korelátem přesvědčení o nutnosti postupné katharsis poznávajícího. Lze to říci i tak, že větší pozornost věnovaná empirii vede nakonec Augustina k tomu, aby svou koncepci touhy doplnil o analýzu paměti, která se pro něj v otázce hledání Boha stává právě tak konstitutivní.

Augustinovo kritérium hledání se tedy nemusí nutně opírat jen o (zprvu bezděčnou) spontaneitu touhy, ale také o činnost a strukturu paměti, jež ve svém médiu spojuje obsahy empirické (affectiones) a nečasové (res ipsae, notiones impressae). Myslet spojení gaudium de veritate na základě této simultaneity ale vyžaduje postupné zpřítomnění hlubšího významu obou těchto pojmů. To s sebou přináší nejen posun v chápání pojmu pravdy (z poznání uloženého v paměti se stává Pravda jako měřítko či zdroj pravdivosti), ${ }^{192}$ ale také posun v chápání pojmu radosti, který

191 K motivu neprůhlednosti ducha pro sebe sama, který je charakteristický pro Augustina na rozdíl od Plótina, srv. L. Karfíková, Anamnesis.

192 Srv. Augustin, Confess. VII,17,23 / CCL 27,107: „Když jsem tedy zkoumal, na základě čeho jsem usuzoval, jak jsem usuzoval, nalezl jsem nad svým myšlením podléhajícím změně pravou věčnost tvé pravdy, která žádné změně nepodléhá." (hoc ergo quaerens, unde iudicarem, cum ita iudicarem, inveneram incommutabilem et veram veritatis aeternitatem supra mentem meam commutabilem.) 
je v Augustinově textu postupně přeznačen biblickými citacemi, v nichž získává stále více theologický význam. ${ }^{193}$

\subsubsection{Exkurs k příběhu}

Ilustraci onoho ,pokulhávání“ a hledání původního spojení v jeho theologickém významu je možné vystopovat i v Augustinově př́íběhu, jenž také naznačuje, proč je identifikace blaženého života jako radosti z Pravdy nesnadná. Aniž by zde bylo možné uvést všechna relevantní místa, pokusíme se naznačit, že Vyznání věnují od počátku pozornost vzájemnému vztahu radosti a pravdy ještě předtím, než je jejich spojení ztotožněno s radostí z Boha. Hned v první knize Augustin říká, že se už jako dítě „,ve svých titěrných myšlenkách o nejnepatrnějších věcech těšil z pravdy“. ${ }^{194}$ Dodává ale, že zdroj jeho omylů a trápení spočíval v tom, že pravdu nehledal v Bohu, nýbrž v jeho tvorech. ${ }^{195}$ Ve třetí knize ukazuje, že sice prahnul po pravdě, ale nehledal Boha nahlédnutím mysli (secundum intellectum mentis), nýbrž tělesným smyslem (secundum sensum carnis) ${ }^{196}$ Už byla řeč o radosti ze svobodných umění (zmíněné ve IV. knize), již však ještě neprovázela znalost původu jejich pravdivosti. Šestá kniha zachycuje jakési záblesky úsilí dosíci spolu s přáteli pravé radosti (verum gaudium) ${ }^{197}$ a vzrůstající odhodlání zasvětit se výhradně hledání pravdy (sola inquisitio veritatis). ${ }^{198}$ A bylo by možné pokračovat citací míst, která zmiňují hledání moudrosti (již Augustin s blažeností spojuje). ${ }^{199}$ Důležitější je ale otázka, zda jsou tyto obsahy paměti, jejichž simultánní spojení zůstává v průběhu hledání implicitní, podle Augustina přítomny v momentě (roz)poznání.

Rozhodující je v tomto ohledu, jak už víme, kniha sedmá, která popisuje objev věčnosti Boží pravdy a vidění toho, co (opravdu) je. Přechodné trvání tohoto zření Augustin vysvětluje svou slabostí. Snad tedy není

193 Paradigmatem takového přeznačení je Augustinův referát o tom, co nalezl a co nenalezl v knihách platoniků (srv. tamt., VII,9,13-14 / CCL 27,101-102).

194 Srv. tamt., I,20,31 / CCL 27,17.

195 Ačkoli se tedy Augustin podle svých slov v dětství k Bohu modlil (tamt., I,9,14 / CCL 27,8), aby nebyl bit, a slýchal o Kristu od své matky (tamt., I,11,17 / CCL 27,9), tehdy ještě jeho nepatrná obeznámenost připouštěla, aby na něj pozapomněl, jak se vysvětluje dál v souvislosti se zalíbením v literární fikci (tamt., I,13,20 / CCL 27,11).

196 Srv. tamt., III,6,11 / CCL 27,32-33.

197 Srv. tamt., VI,6,9-10, zejm. VI,6,9 / CCL 27,79.

198 Srv. tamt., VI,11,19 / CCL 27,86.

199 Srv. tamt., III,4,7 / CCL 27,30. 
nahodilé, když v bezprostředně následující pasáži řekne, že začal hledat cestu, jak získat sílu, která by mu umožnila, aby se z Boha (trvaleji) těšil (frui), a kterou nenašel, dokud nenašel Krista coby prostředníka mezi Bohem a lidmi. ${ }^{200}$ (Jde-li o Augustinovo obrácení v knize osmé, jistě bylo př́činou velké radosti, již ovšem zpočátku neměl ani tak jeho aktér, jako spíše jeho matka Monika.) ${ }^{201}$ Pokud bychom ale v prvních devíti knihách Vyznání hledali syntézu nahlédnutí pravdy a zkušenosti vnitřní radosti v pojmu blaženého života, nejvýmluvnější bude závěr ostijské vize z knihy deváté:

„A kdyby tento stav prodléval a jiná vidění nesrovnatelně nižšího původu by se vytratila, takže by toto jediné uchvátilo, pohltilo a zakrylo dlaní ve vnitřní radosti svého pozorovatele - není snad věčný život právě takový, jako byl tento okamžik nahlédnutí, za nímž jsme se s povzdechem ohlédli, neznamená právě toto ,vejdi v radost svého Pána‘ (Mt 25,21)?“202

Snad toto místo, více než jiná, poukazuje k nečasové simultaneitě, s níž si Augustin spojuje blažený život; zde ovšem - jak plyne ze souvislosti celé pasáže - promítaný do eschatologické budoucnosti. Možná tedy skutečnému rozpoznání hledaného odpovídá nakonec lépe rozhovor v Ostii než novoplatónské nahlédnutí z knihy VII. Zároveň citovaná pasáž dobře ilustruje biblické přeznačení pojmu radosti. Jde-li o samotné spojení gaudium de veritate, ${ }^{203}$ není asi bez významu, že v prvním Pavlově listu Korintským (který Augustin už v raných dílech cituje právě v souvislosti s blaženým životem a trojicí víra, naděje, láska - fides, spes, caritas) se z pravdy raduje láska. ${ }^{204}$ Tato třetí ctnost má podle sv. Pavla

200 Srv. tamt., VII,18,24 / CCL 27,108.

201 Srv. tamt., VIII,12,30 / CCL 27,132.

202 Srv. tamt., IX,10,25 / CCL 27,148: si continuetur hoc et subtrahantur aliae visiones longe imparis generis et haec una rapiat et absorbeat et recondat in interiora gaudia spectatorem suum, ut talis sit sempiterna vita, quale fuit hoc momentum intellegentiae, cui suspiravimus, nonne hoc est: Intra in gaudium Domini tui? Srv. Plótinos, Enn. I,6,7,15 nn.

203 Existuje i filosofický kontext, v němž se toto spojení vyskytuje, totiž Senecův spisek De vita beata, 4,5, vyd. J. W. Basore, Loeb Classical Library, 254, Cambridge 1965, str. 110: ex cognitione veri gaudium grande et immotum. Jeho celkové vyznění ale Augustinovu smýšlení spíše neodpovídá.

204 Srv. 1K 13,8-13; Augustin, De beata vita, 4,35 / CCL 29,85; Solil. I,6,13 - 7,14 / CSEL 89,21-23. 
jako jediná eschatologický význam, a proto ji lze myslet (už v Augustinových raných Hovorech se sebou samým) zároveň jako vztah k dosud nepřítomnému předmětu touhy či hledání i jako stav radostné kontemplace prrítomného dobra. ${ }^{205}$

Kdybychom se měli vrátit k výchozí aporii hledání, která nakonec vyústila v otázku povahy spojení gaudium de veritate, je snad namístě ptát se, jak se má simultaneita paměti k transcendentní jednotě, o níž Augustin mluví v souvislosti s Boží věčností, v níž je vše naráz $\left(\right.$ simul). ${ }^{206}$ Zdá se, že pro Augustina může být na jedné straně jakási simultaneita v nedokonalé podobě stále ještě rysem paměti (podobně jako jsou v memoria nějak zahrnuty i věci samy, které jsme dosud neaktualizovali), na druhé straně se ale přirozenost touhy zaměřuje $\mathrm{k}$ jednotě či simultaneitě (a zároveň z ní pramení), která pamět' přesahuje a je předmětem úvah v XI. knize Vyznání.

\section{Závěr}

Sledování první otázky Menónovy aporie - totiž otázky možnosti samotného hledání - ve Vyznáních vyústilo ve zkoumání touhy v její ambivalentní povaze: touha směřuje ze své podstaty $\mathrm{k}$ Bohu jako dosud neznámému, ale zároveň se zprvu vždy řídí něčím, co již zná. Sledování druhé otázky - totiž otázky možnosti rozpoznání hledaného - ukázalo, že X. kniha tohoto spisu nepředstavuje ani tak - v pořadí třetí - výstup k Bohu, ale spíše zkoumá jeho předpoklady, nebot' podle Augustina nese každý člověk neurčité, implicitní poznání Boha ve své paměti. Obě tyto linie tázání vedly nakonec $\mathrm{k}$ analýze blaženého života jako něčeho, co známe, čeho reprezentaci nějak chováme ve své paměti a co nakonec může vést $\mathrm{k}$ nalezení Boha, ačkoli on sám pamět' přesahuje. Jádrem zkoumání beata vita - vymezené Augustinem jako radost z pravdy - se pak ukázala být samotná povaha spojení těchto dvou zdánlivě nespojitých typů obsahů paměti: různých pravdivých poznatků a rozličných radostí z rozmanitých věcí. Smyslem výkladu o blaženosti se tedy zdá být

205 Srv. tamt., I,6,13 / CSEL 89,21: caritas, qua videre perfruique desideret; I,7,14 / CSEL 89,3: Sed cum post hanc vitam tota se in Deum collegerit, caritas restat qua ibi teneatur. K tomu srv. L. Karfíková, Jazyk touhy, str. 95-96.

206 Srv. např. Augustin, Confess. XI,7,9 / CCL 27,198: Neque enim finitur, quod dicebatur, et dicitur aliud, ut possint dici omnia, sed simul ac sempiterne omnia: alioquin iam tempus et mutatio et non vera aeternitas nec vera immortalitas. 
doplnění augustinovské představy touhy určitou koncepcí simultaneity paměti; při činnosti vzpomínání, která odhaluje skrytější rovinu paměti, se nakonec mnohost těchto specifických obsahů ukazuje být sjednocena tak, že vposledku poukazuje k ještě hlubší jednotě, z níž samy tyto obsahy či (terminologií jiných spisů) „,tisky“ pocházejí. V Augustinově výkladu se proto postupně obrací pozornost od pravd uložených v paměti k Pravdě, jíž jsou pravdivé všechny věci, a jeho popis různých - dobrých i odvržených - radostí se zaměřuje na radost z této Pravdy, a tedy Boha. Oběma těmto přechodům od mnohosti obsahů v paměti, které se postupným a - jak je dobře vidět $\mathrm{v}$ autobiografické části spisu - velmi nesamozřejmým procesem vzpomínání dotýkají jednoty, z níž pocházejí, odpovídá také Augustinovo závěrečné shrnutí jeho analýzy paměti, podle nějž nakonec Bůh sám v paměti k nalezení není, nebot' ji přesahuje. Augustinův postup hledání Boha v paměti v X. knize ovšem stále zůstává - přinejmenším ve srovnání s ranými spisy - specifický tím, jakou roli přisuzuje affectio radosti a vzpomínkám na ni.

Rozhodující posun, v němž Augustin odlišuje pravdivé obsahy paměti od Pravdy, která je jakožto pravdivé ukazuje, bývá často opisován metaforikou světla. Augustin také v průběhu vyprávění hovoří o skryté Boží přítomnosti, která jej provázela i v době, kdy ji ještě nerozpoznal. ${ }^{207}$ Přesto je v autobiografické (a zároveň aporetické) části Vyznání (knihy I-X), pokud jde o výslovné zmínky o vnitřním světle Pravdy, poměrně stř́ímý. ${ }^{208}$ Snad je tomu tak z důvodu, který sám formuluje v dialogu O učiteli: „A když se [racionální duše] někdy mýlí, není to chyba Pravdy, od které se učí, podobně jako není chybou světla, které je venku, že se často zmýlí tělesné oči.“" ${ }^{209}$ Pro Vyznání je tedy příznačné, že častější zmínky o „radosti ze světla Pravdy“ se objevují až v knihách XI-XIII. ${ }^{210}$

207 Srv. výše, pozn. 33.

208 Augustin hovoří v knihách I-X o věčném světle Pravdy v kontextu svého duchovního výstupu (Confess. VII,10,16 / CCL 27,103) a později si na něj patrně vzpomíná (tamt., IX,4,10 / CCL 27,139). Na samém konci X. knihy je pak důležitá pasáž, která se retrospektivně vrací k analýze paměti a hovoří o věčném světle, s nímž se Augustin o všem radil (tamt., X,40,65 / CCL 27,190-191 - viz výše, pozn. 167).

209 Srv. týž, De mag. 11,38 / CCL 29,196: Et si quando fallitur, non fit vitio consultae veritatis, ut neque huius, quae foris est, lucis vitium est, quod corporei oculi saepe fallantur...

210 Srv. týž, Confess. XI,8,10 / CCL 27,199, kde ovšem není řeč o světle, ale o ,stálé Pravdě“, z níž se radujeme. A dále zejm. dvě pasáže, v nichž se výslovně hovoří o radosti ze světla pravdy: tamt., XII,28,38 / CCL 27,238 (gaudent in luce veritatis tuae); XIII,18,23 / CCL 27,254. 
Jestliže jsme v tomto textu sledovali perspektivu aporie hledání (spíše než zmínky o světle, které toto hledání vede), jedná se bezpochyby o pohled jednostranný, protože se více zaměřuje na iniciativu poznávajícího než na součinnost či přítomnost Boha, který této iniciativě podle Augustina vychází vstříc a někdy i sám ,,podněcuje“ (admonere) k hledání. ${ }^{211}$ Domnívám se však, že toto hledisko je v souladu s Augustinovým vlastním postupem v prvních devíti knihách Vyznání a zejména s analýzou paměti z knihy X, jejímž smyslem je filosofická - a nejen náboženská - apologie hledání Boha. Metaforika světla (s níž se někdy spojuje tzv. teorie iluminace) v sobě v určité své variantě může snoubit obojí: představu Boží aktivity vycházející vstříc člověku i hledání, které vychází z určitých (Bohem darovaných) dispozic lidské přirozenosti. Výklad v X. knize lze nicméně chápat také jako určitý pokus o filosofickou (a zčásti také narativní) interpretaci tohoto - Augustinem často užívaného - obrazného způsobu vyjadřování, který zdědil jak z Janova evangelia, tak $\mathrm{z}$ antické myšlenkové tradice. ${ }^{212}$

\section{ZUSAMMENFASSUNG}

Die zeitgenössischen Interpretationen der Confessiones, insbesondere des I. und des X. Buches, verstehen die Frage, die sich Augustinus stellt - nämlich die Frage nach der Gottsuche - als eine Variante des Menon-Paradoxes: Wie können wir Gott suchen, wenn wir ihn bisher nicht kennen gelernt haben? Und ist es überhaupt möglich, eine intentionale Beziehung zu Gott, z.B. eine Sehnsucht nach Gotteserkenntnis, zu haben, wenn wir keine Erkenntnis von ihm haben? Und wie erkennen wir, dass dasjenige, was wir gefunden haben, auch das ist, was wir gesucht haben? Einen Orientierungspunkt für unsere Suche können wir laut dem X. Buch der Confessiones in der impliziten Erkenntnis des seligen Lebens (beata vita) finden, die jedes vernünftige Wesen in irgendeiner Weise im eigenen Gedächtnis hat. Das Nachdenken über diese Erkenntnis führt Augustinus zu der Ansicht, dass beata vita Freude an der Wahrheit (gaudium de veritate) darstellt. Aus diesem Grund konzentrieren

211 Srv. výslovně např. týž, De beata vita, 4,35 / CCL 29,84: Admonitio autem quaedam, quae nobiscum agit, ut Deum recordemur, ut eum quaeramus, ut eum pulso omni fastidio sitiamus, de ipso ad nos fonte veritatis emanat.

212 Tato práce byla podpořena programem Univerzitní výzkumná centra UK č. 204053. 
sich diejenigen Interpretationen, die ihre Aufmerksamkeit auf das Motiv von Menons Aporie in den Confessiones lenken, gewöhnlich auf diese zwei Komponente des seligen Lebens oder alternativ auch auf die Frage, in welchem Sinne die Wahrheit ein Gegenstand der Freude sein kann. Der erste Teil des Beitrags unternimmt den Versuch, die Stellung der Menon-Aporie im Gesamtentwurf der Confessiones zu bestimmen. Der zweite Teil konzentriert sich auf die Untersuchung des Wesens der Beziehung zwischen gaudium und veritas, die jedoch nur auf dem Hintergrund einer detaillierten Analyse des X. Buches erhellt werden kann. Zugleich versucht er dem Leser zu vermitteln, welche besondere Rolle Augustinus der Erinnerung an die vergangene Freude zuschreibt.

SUMMARY

Recent philosophical interpretations of the Confessions, especially of Books I and X, often approach the question that Augustine raises there, i.e., that of a search for God, as a version of Meno's paradox: How can we search for God if we don't know him yet? Is it even possible to have any intentional relation to God, such as a desire to know him, if we lack any knowledge of him? And how can we ever know that we have found what we were searching for? According to Book X of the Confessions, we can find a point of orientation for this quest in an implicit knowledge of happy life (beata vita), one that every rational being somehow has in their memory. By considering this knowledge, Augustine is led to the assertion that the beata vita is joy in truth (gaudium de veritate). That's why the interpretations following echoes of Meno's aporia in the Confessions usually focus on these two components of happy life, or alternatively on the sense in which truth can be an object of joy. The first part of the paper seeks to determine the role of Meno's aporia in the Confessions as a whole. The second part focuses on the nature of the connection between gaudium and veritas which can only be understood against the background of a detailed analysis of Book X; it also draws the reader's attention to the peculiar role ascribed by Augustine in this context to the remembering of a past joy. 